$\begin{array}{ll} & \text { Kastamonu Eğitim Dergisi } \\ \text { Kastamonu Education Journal } & \text { Kabul Tarihi/Received: } 25.01 .2019 \\ \text { Ocak 2020 Cilt:28 Sayı:1 } & \text { Kabihi/Accepted: } 11.06 .2019\end{array}$

\title{
Etkinliklere Dayalı Ontolojik Metin Analizi Yönteminin Yedinci Sınıf Öğrencilerinin Şiir Çözümleme Başarılarına Etkisi1
}

\section{The Effect Of Ontological Text Analysis Method Based On Activities On The Poem Analysis Success Of Seventh Grade Students \\ İzzet ŞEREF ${ }^{2}$}

\section{Öz}

Bu araştırmanın amacı, ontolojik metin analizi yönteminin şiir öğretiminde kullanılabilmesi amacıyla ortaokul yedinci sınıf öğrencilerinin düzeylerine uygun etkinlikler hazırlanıp hazırlanamayacağını araştırmak ve bu yöntemin yedinci sınıf öğrencilerinin şiir çözümleme başarılarına etkisini ortaya koymaktır. Çalışmada ön test-son test kontrol gruplu deneysel desen kullanılmıştır. Araştırmanın çalışma grubunu aykırı durum örnekleme yöntemiyle seçilen Erzurum il merkezindeki sosyoekonomik seviye ve 2014 yılı TEOG başarı sıralaması açısından düşük dereceli bir ortaokul (O1) ile yüksek dereceli bir ortaokuldaki (02) toplam 76 yedinci sınıf öğrencisi oluşturmaktadır. Uygulama 2015-2016 eğitim ve öğretim yılı boyunca gerçekleştirilmiştir. Veriler; araştırmacı tarafından geliştirilen "Şiir Çözümleme Formu (ŞÇF)" aracılığıyla toplanmıştır. Verilerin analizinde Mann Whitney U Testi ve Wilcoxon Testi kullanılmıştır. Araştırmadan elde edilen bulgulara göre etkinliklere dayalı ontolojik metin analizi yönteminin her iki okuldaki deney grubu öğrencilerinin şiir çözümleme başarılarını artırdığı anlaşımıştır.

Anahtar Kelimeler: etkinliklere dayalı ontolojik metin analizi, şiir öğretimi, Türkçe eğitimi.

\section{Abstract}

The purpose of this study is to investigate whether activities may be prepared for secondary school students to be used in teaching poems with Ontological Text Analysis Method; and determine the effect of this method on the poem analysis skills. The experimental design with pre-test post-test control group were used in this study. The study group consisted of 76 seventh grade students who were selected with Extreme or Deviant Case Sampling Method and who were studying at a secondary school with low success level $\left(\mathrm{O}_{1}\right)$ and at another secondary school with high success level $\left(\mathrm{O}_{2}\right)$ in terms of 2014 TEOG Exam and socio-economic levels in the city center of Erzurum The study and control groups were determined by lottery method from among the classes of the teachers who were teaching seventh graders in the schools. The application was performed in 2015-2016 Academic Year. The data were collected with the "Poem Analysis Method (PAM)", which was developed by the author of the study. The Mann Whitney UTest and Wilcoxon Test were used in the analyses of the quantitative data. According to the findings obtained in the study, it was concluded that the Ontological Text Analysis Method Based on Activities increased the poem analysis success levels of the Study Group students in both schools.

Keywords: ontological text analysis method based on activities, poem education, Turkish education.

\footnotetext{
${ }^{1}$ Çalışma, araştırmacının "Etkinliklere Dayalı Ontolojik Metin Analizi Yönteminin Yedinci Sınıf Öğrencilerinin Şiir Çözümleme Başarılarına ve Şiir Tutumlarına Etkisi" adlı doktora tezinden yararlanılarak hazırlanmıştır.

2 Tokat Gaziosmanpaşa Üniversitesi Türkçe ve Sosyal Bilimler Eğitimi Bölümü, Tokat, Türkiye, http://orcid.org/0000-0002-2379-1373
} 


\section{Extended Abstract}

Introduction: The purpose of this study is to determine the effects of the activities prepared on the basis of the ontological text analysis method (OTAM) on poem analysis success of secondary school seventh grade students. For this purpose, the following question was searched in the research: 1. Is the ontological text analysis method based on activities effective in increasing the poetry analysis success of the seventh grade students?

Method: The research is planned as an experimental design with pre-test-posttest control group. In this context, primarily experimental and control groups were determined. In order to determine the poem analysis and poetic attitudes of the experimental and control groups at the beginning of the application, Poem Analysis Form (PAF) developed by the researcher was applied. Afterwards, the poems in Meram Publications' 7th Grade Turkish Textbook have been evaluated according to the method of ontological text analysis and the activities are designed according to the students' levels. The designed activities were carried out by instructors during a school year. The PAF was used to determine the final test scores of the experimental and control groups at the end of the application period. The study group of this study was determined with Extreme or Deviant Case Sampling Method. Two schools were selected as a low grade secondary school (SS1) and a high grade secondary school (SS2) in terms of the socioeconomic level in the city center of Erzurum and the success rate of TEOG in 2014 by the said sampling method. Turkish teachers were informed about the studies to be carried out in these schools and teachers who were volunteers and also entered the classes of the two seventh classes were given priority. In this way, the selection of the experimental and control groups was completed by drawing lots between the two seventh grades chosen in both schools. 9 girls, 8 boys for study group (S1) ; 10 girls, 7 boys for control group (C1) in the SS1 and 11 girls, 10 boys for study group (S2) ;7 girls and 14 boys for control group (C2) in the SS2, a total of 76 students participated in the study. Equivalence of study and control groups; are examined by taking into account Turkish lesson report marks in 6.grade, Turkish lesson and the condition of liking poems. In order to determine whether the experimental and control groups are equivalent in terms of the stated variables, it was firstly examined whether the data were normally distributed. Normality graphs of the data were evaluated and it was determined that there was no normal distribution. The nonparametric Mann-Whitney U Test was used in the analysis because the normality assumptions were not adequate.

The data of the study were collected by Ontological Text Analysis Activities (OTAA) and Poem Analysis Form (PAF) developed by the researcher. When designing OTAA, cognitive and affective levels of seventh graders were taken into consideration. Ontological text analysis method was used as a method. Ontological text analysis method is based on four layers: 'sound layer', "layer of meaning units", "object and the character layer" and "fate layer". When designing activities, basically these layers were taken into account. While developing the PAF, the layers of ontological text analysis method were taken into consideration, but it was regarded that the questions in the form were in accordance with the mental skills of the students at the level of knowledge and comprehension. In the form are given variances like firstly gender, academic achievement of Turkish lesson, liking poem, liking Turkish lesson. Faruk Nafiz Çamlıbel's poem; "Çoban Çeşmesi" was preferred as a text. In the analysis of the data collected by this form, the answer key was first prepared by the researcher and the answer key was finalized by taking the opinion of two experts who are experts in the field to control the answer key. According to the answer key, the PAFs were first read by the researcher and graded over 100 points. The forms were studied by two researchers who were experts in the field besides the researcher. The scores of the students included in the analysis were determined by taking the average of the points given by the three researchers. The ultimate data were analyzed by considering the experimental process according to the research questions. As a result of this integrated evaluation, it was understood that normality assumptions were not adequate and the nonparametric Mann-Whitney $U$ and Wilcoxon tests were used to analyze the data.

Findings: It is concluded that the poem analysis approaches applied in Meram Publications 7th Grade Turkish Lesson Teacher Guide Book in SS1 and SS2 are not effective in increasing the poetry analysis success of seventh graders and the experimental process based on OTAA is effective in increasing the poetry analysis success of 7th grade students. This result shows that OTAA can be used as an effective tool in teaching poetry.

Discussion and Conclusion: OTAA offers the opportunity to discuss, evaluate, interpret and analyze poetry in every aspect. Students will be able to discover the basic elements of poetry (rhyme, meter, verse, strophe, quatrains, repetitions, etc.), to find meaning associations in poetry, to critically evaluate the images in poetry, to analyze the meaning of the poem in terms of meaning and structure. It becomes more possible with OTAA. OTAA act from the idea that none of the elements in poetry are random, but that it has a duty. For this reason, it takes into account everything related to the poetry in poetry teaching. In other words, it offers a broad study area for teachers. Karadeniz (2012) related to this result obtained from the research, in her study, she investigated the effect of modern analysis approaches on poetry analysis skills, she designed activities for poetry analysis with modern analytical approaches and 
applied in the sample of second grade students of Turkish language teaching. Karadeniz stated that modern analysis approaches, including ontological text analysis method, are effective in developing students' poetry analysis skills.

In SS1 and SS2, many activities were performed in order to evaluate the students' poetry with all components while activities prepared with the attention expressed in the method section were applied. Therefore, students not only gained success in poetry analysis; they have increased their knowledge of both formal and semantic analysis of structures such as sentence, phrase, word. This judgment has been achieved with a steady increase in students' achievements in activities. In this respect, Dunning (1966) also stated that it is necessary to approach poetry from a plural point of view in order to teach an effective poetry, multiple approaches should be taken into consideration in the teaching process of poetry. In addition, the researcher stated that the teaching of poetry is more versatile, meaning that students can achieve more successful results when they are motivated by both affective and cognitive aspects. 


\section{Giriş}

Türkçe Sözlük'te şiirin ahenk ögesine dayalı olduğu vurgulanarak tanımı şöyle yapılmıştır: "Zengin sembollerle, ritimli sözlerle, seslerin uyumlu kullanımıyla ortaya çıkan, hece ve durak bakımından denk ve kendi başına bir bütün olan edebî anlatım biçimi”dir (Türk Dil Kurumu, 2011: 2224). Bir edebî tür olan şiir gücünü dilden alır; şiirin araç gereci, hamuru, mayası dildir (Aksan, 2011: 15). Düzyazı için dil, bir araçtır, şiirde ise dil hem araçtır hem de ortamdır. Dil, bir yerde şiirin gövdesi gibidir (Binyazar ve Öztekin, 1978: 32). Şiir, hem yapı hem de içerik açısından diğer edebî türlerden ayrılır. Ümitler, hayaller, aşklar hep şiirle ifade edilir. Ancak her ölçülü ve kafiyeli sözün de şiir olması mümkün değildir. Şiir için en temel unsurların başında ahenk gelmektedir. Ahenk ise ritim ve armoni ile tamamlanır. Ritim, ölçü ve kafiye; armoni ise aliterasyon ve asonanslardır (Aytaş, 2006: 13).

Tanımlarda vurgulanan temel unsur, şiirde kullanılan dilin rastgele olmadığıdır. Bu bakımdan Türkçenin seçkin şiir örneklerinin dil öğretiminde araç olarak kullanılması, süreci başarılı kılmada büyük bir kolaylık sağlayacak, şiir aracılığıyla öğrencilerin okuma, konuşma, dinleme ve yazma becerilerinin gelişmesi kolaylaşacaktır. Söz gelimi, öğrencilerin dil bilgisel yapıların farklı kullanım alanlarını keşfetmelerini somut olarak gerçekleştirmede ya da dilin duygu, hayal ve düşünceleri anlatmada ne dereceye kadar yetkin olduğunu göstermede şiir inceleme çalışmalarına çokça yer verilebilir. Diğer yandan sesler, yapılar, sözcükler arasında uyum veya ahengin ne demek olduğu şiir tahlilleri yapılarak öğrencilere gösterilebilir. Böylelikle öğrencilere dil estetiği bakımından bir bilinç kazandırılabilir.

Şiir, çok anlamlı edebî bir tür olduğu için şiiri oluşturan sözcüklerin birden fazla anlamı olabilir. Bunun sebebi şiirsel bağlam içerisinde bir araya gelmiş olan sözcüklerin bağlam dâhilinde farklı şekillerde ve içeriklerde değerlendirilmesidir. Dolayısıyla şiirsel bağlamda yer alan sözcüklerin, çoğunlukla sözlük anlamı dışında bir araya gelmiş olabileceği göz ardı edilmemelidir. Şiirin bu özelliği ona çok yönlü bir yapı kazandırmıştır. Şöyle ki şiirde sıradan metinde bir araya gelemeyecek sözcükler yan yana gelebilir ve bunlar birlikte bir anlam alanına işaret edebilir. Öğrencilere bu durumu anlatabilmek amacıyla gerçekleştirilen şiir etkinlikleri sözcükleri anlam bakımından sınıflandırmada, birtakım dil bilgisel sorgulamalar yaparak Türkçenin imkânları dâhilinde yeni anlatım yolları keşfetmede yol gösterici olabilir.

Bu çalışmada ifade edilen gerekçe doğrultusunda ontolojik metin analizi yöntemi temelli şiir inceleme etkinlikleri tasarlanmış ve öğrencilerin söz konusu etkinliklerle birlikte şiir çözümleme başarılarının nasıl değiştiği sorgulanmıştır.

\section{Metin Çözümlemede Modern Bir Yöntem Olarak Ontolojik Metin Analizi}

Sanat eseri veya estetik obje, bir var olan olarak, ya bir heykel ya bir tablo veya şiirdir. Bir heykel yapı olarak taş, tunç veya odundur. Resim; bez, kâğıt veya boyadır. Şiir ise sesten başka birşey değildir. Şiiri seslerden ayıran ve onu seslerin üzerine yükseltip bir estetik obje yapan başka bir alan vardır. Yani varlık tarzı bakımından, estetik objenin reel, duyusal yapısının üzerinde, bu reel yapıdan mahiyetçe ayrı başka bir alanın da varlığı bilinmektedir. Bu alan reel olmayan, duyuüstü, irreel bir varlık alanıdır. Kısacası estetik obje veya sanat eseri reel tabakanın yanında irreel tabakayı da içine alır. Dolayısıyla her estetik objenin, yani sanat eserinin; reel, duyusal olan bir ön yapı ve irreel, mana veya arka yapı şeklinde zaruri olarak iki ayrı ontik yapıdan meydana geldiği söylenebilir. Ön yapı, sujeden bağımsız olarak kendi başına var olabilirken arka yapı sujeye bağımlı bir varlık tarzına sahiptir. Bu düşünce sanat eserinin ya da estetik objenin varlık tarzı bakımından reel olan bir ön yapı ile irreel olan bir arka yapıdan meydana gelmiş ontik bir bütün olduğunu göstermektedir (Tunalı, 2011: 16-19).

Ontolojik estetik/sanat ontolojisi, ne sadece sujenin ne de objenin yanında yer alır. Yani ontolojik estetik, sujeobje ikilemi karşısında tamamen bütüncül bir tavır alır ve bu anlamda bütüncül bir estetik olduğu söylenebilir. Daha doğrusu ontolojik estetik sujeyi dışarıda bırakmak yerine sujenin objede olduğunu ileri sürer (Tunalı, 2011: 25).

Sanat eseri, gerçekte ontik bir bütün olduğuna göre onu olduğu gibi incelemek, yani ontolojik bir açıdan araştırmak kadar tabii ve olguya/görüngüye uygun bir metot düşünülemez. Bu anlamda ontolojik estetik, yalnız estetik alanına yeni bir görüş getirmekle kalmıyor, aynı zamanda sanat eserini ontik bir bütün olarak kavrayıp açıklaması ile de sanat tarihine yeni bir metot kazandırmış oluyor (Tunalı, 2011: 26)

Tunalı'ya (2011: 15) göre ontolojik yaklaşımın sanat eseri karşısında aldığı tavır, gerek psikolojik gerek olgusal estetiklerden büsbütün başkadır. Ne psikolojik estetik gibi estetik objeyi, sujenin duygu, tasavvur ve bu gibi unsurlarından ibaret olarak görür ne de olgusal estetik gibi onu reelitesinden ve sujenin duygu hâlinden sıyırıp objektif bir mahiyet alanı olarak düşünür. Ontolojik yaklaşım, farklı tabakalardan meydana gelen sanat eserini ontik bir bütün olarak kabul eder. Özellikle şiir analizlerinde metnin içerdiği şekle ve içeriğe ait değerleri, sanat yönünü, şiirselliğini tespit etmede bir ölçü ortaya koyar. 
Ontolojinin felsefi bir disiplin olarak gelişmesi ile ilgili yapılan çalışmalarda, metodu sanat eserlerine en iyi uyarlayan estetikçinin Nicolai Hartmann olduğu vurgulanmaktadır. Nicolai Hartmann, bir sanat eserinin yapısını "ön yapı (vonderground)" ve "arka yapı (hinterground)" şeklinde ikiye ayııır. "Ön yapı, açık olarak bilinen bir tabakadır; bağımsız, ontik bakımdan kendi başına var olan reel tabakadır. Arka yapı ise asıl tinsel içeriktir, ama bağımsız bir varılık tarzına sahip değildir" (Tunalı, 2014: 58). Yani "bu iki yapı öyle iç içe girmiş, öyle girift olmuştur ki sadece bir tek objeymiş gibi görünür"ler (Tunalı, 2014: 61).

Edebî eserlerde çok anlamlılık esastır. Bir edebî eseri, tek bir yönden inceleyip anlamak mümkün değildir. Son dönemde verilen eserlerdeki çok sesli yapı düşünüldüğünde karmaşıklığın boyutunun daha da arttığı söylenebilir. Bundan dolayı çok yönlü bakış açısı sağlayan yaklaşımları kullanmak kaçınılmaz olmuştur. Ontoloji, "metni oluşturan anlam katmanlarını inceleyen" (Tökel, 2007: 536) bir yaklaşım olarak estetik alımlayıcıya farklı bakış açıları sunmaktadır.

Ontolojik estetiğin temel sorunsalı, edebiyat eserindeki varlık tabakalarını ortaya çıkarmaktır. Ancak edebiyat eserinin varlık bakımından çok katmanlı bir özellik gösterdiği unutulmamalıdır. Çünkü edebiyat eserinin özüne uygun yapısı, onun birçok tabakadan meydana gelmiş bir bütün olmasından ibarettir. Bu yapı içinde ideal varlık, reel varlıkta gerçekleşir. Edebiyat eserinde varlık tabakalarından ilk bahsedenin Roman Ingarden olduğu söylenmişti. Tunalı'ya göre Ingarden edebiyat eserinde şu tabakaların varlığından söz eder:

\section{Sözcük sesleri tabakası}

2. Farklı derecelerdeki anlam birlikleri tabakası

3. Farklı şematik görüşler tabakası (Nesne tabakası)

4. Tasvir edilen şeylerin ve onların alınyazılarının tabakası (Görme tabakası) (Tunalı, 2014: 89).

Sözcük sesleri tabakasında, bir edebî metinde geçen sözcüklerin ses değerleri ve bunların sözcüğün anlamı ile ilgisi üzerinde durulur. Çünkü "ses materyali, kelimenin anlamını koruyan ve saklayan bir mahfaza" gibidir (Tunalı, 2014: 90). Anlam birlikleri tabakasında ise en büyük anlam birliği olan cümleye yoğunlaşılır. Daha sonra cümlede geçen tamlamalar ve sözcükler cümle içinde yüklendikleri yeni anlam/anlamlar bakımından sorgulanır. Bu tabaka aslında sözcük sesleri tabakasına dayanmaktadır. Anlam tabakasında, sözcük sesleri ve yapının anlamla ilişkisi kurulmaya çalışılır. Yani ne ses ne de anlam yok sayılır. Ancak edebiyatın temel hedefi anlam değildir, anlam diğer tabakalara götüren bir araçtır. Anlam tabakasının üstünde ise nesne tabakası vardır. Bu tabakada edebî eserdeki insanlar, şeyler ve olaylar sorgulanır. Bunların eserin bütünlüğüne katkısı tartışılır. Ancak nesne tabakası, edebiyat eserinde yalnız kendi kendisi için vardır. Yani nesneler tabakası, "hedefi kendisinde olan tabakadır, oysa öbür tabakaların hedefi nesneler tabakasıdır" (Tunalı, 2014: 99). Dördüncü tabaka olan alınyazısı tabakasında ise edebiyat eserinin evrensel değeri tartışılır.

Tunalı (2014: 101), Roman Ingarden'ın tasvir edilen objelerin "görünüşü" üzerinde değil de "sanısı" üzerinde durduğunu gerekçe göstererek onun meseleyi ontolojik olarak Nicolai Hartmann kadar iyi kavrayamadığını düşünür. Çünkü tasvir edilen şeyleri sanı olarak kavramak, ister istemez reeliteye nazaran şeyleri varlık yönünden aşağı skalaya çeker. Daha genel bir ifadeyle Roman Ingarden, tabakaları birer varlık tarzı olarak belirlememiştir. Ses, anlam ve nesne tabakaları çok katmanlıdır. Ancak görme tabakası ontik olarak belirlenmemiştir. Kısacası Roman Ingarden'ın tabakalar teorisi, bütünüyle tatmin etmediği gibi birçok ontolojik meseleyi de çözmeden bırakıyor (Tunalı, 2014: 107).

Nicolai Hartmann da Roman Ingarden gibi şu dört tabakadan söz eder:

1. En ön tabaka, resimde ve plastikte duyulur olan şeyi karşılar. Bu tabaka edebiyatta, tiyatroda görünebilirliği, işitilebilirliği ifade eder.

2. Bu tabaka, ön tabakanın hemen arkasından gelir ve ön tabakanın aracılığıyla ve onda görünüşe ulaşır. Özellikle tiyatro eserlerinde görünür olur.

3. Bu tabakanın ruhi tabakayı karşıladığı söylenebilir. Tiyatronun vazgeçilmez dayanağı olan ahlaki çatışmalar bu tabakada görünüşe çıkar.

4. Bu tabaka, tabakalar düzeninde en derin tabakalardan birini teşkil eder. Çünkü bu tabaka insanın ruh dünyasıyla değil, onun hayatının bütünüyle yani kaderle ilgilidir (Tunalı, 2014: 109-110).

Anlaşıldığı üzere Ingarden ve Hartmann, edebiyat eserinde dört varlık tabakası olduğunu söylemişlerdir. Ancak iki teoride de eksik yönlerin olduğu tartışmaya açıktır. Tunalı (2014: 111), Hartmann ile Ingarden'ın bu konudaki tutumlarını şu cümlelerle kıyaslar: 
Nicolai Hartmann'ın edebiyat eserinde bulduğu tabakalar, bizi daha yetkin, eklektik olmakla beraber, daha tatmin edici bir tabaka sistemi kurmaya götürebilir. Roman Ingarden'ın tabakalar teorisinde en başarılı yan, hiç şüphesiz kelime tabakasını analiz etmesi, onu ses ve anlam olarak ayırması, sonra bu iki yanı birbirinden farklı iki ontik tabaka olarak görmesidir... Ama ne var ki Ingarden bunlara bir de görme tabakasını katar. Bu elemanı bir tabaka olarak görmek doğru değildir. Onu daha çok bir kategori ya da form prensibi olarak görmek gerekir.

Nicolai Hartmann'a gelince, onun dili bir maddi tabaka olarak görmesine itiraz edilebilir çünkü dil; taş, bronz, odun, toprak, boya çeşidinden bir varlık değildir. Bu bakımdan kelimeyi ses ve anlam diye ayırmakla, Roman Ingarden daha doğru hareket etmiş olur. Ama buna karşılık, Nicolai Hartmann, anlam tabakasını karakter, kader ve kişilik, insanlık ide'leri gibi birtakım tabakalara ayırmakla anlam tabakasını daha somutlaştırmış olur.

Tunalı, bu düşünceleriyle hem Hartmann'ın hem de Ingarden'ın ontolojik estetik metotlarında eksiklikler olduğunu ifade etmiştir. Çünkü gerek Ingarden'ın gerek Hartmann'ın tabakalar teorisinde somut çözümleme, belirsiz bir nitelik taşımaktadır. Ve bunun doğal sonucu olarak her iki teoride de ontolojik analizin metodolojik değeri gücünü kaybediyor. Diğer bir ifadeyle ontolojik tabakalar teorisinin en büyük değeri, sanat eserlerine uygulanmadaki pratik, metodolojik özelliğinden ileri gelir. Tunalı, araştırmacılara pratik bir yaklaşım sunmak amacıyla Hartmann ve Ingarden'ın tabakalar teorisini dikkate alarak bir teori oluşturmuştur. Öncelikle Hartmann'ın ön yapı ve arka yapı teorisini göz önünde bulundurmuştur. Bir eserde temelde ses tabakası ve anlam tabakasının olduğunu ifade etmiştir. Bayram (2003: 12-15), Tunalı'nın geliştirdiği bu teoriyi şu şekilde tablolaştırmıştır:

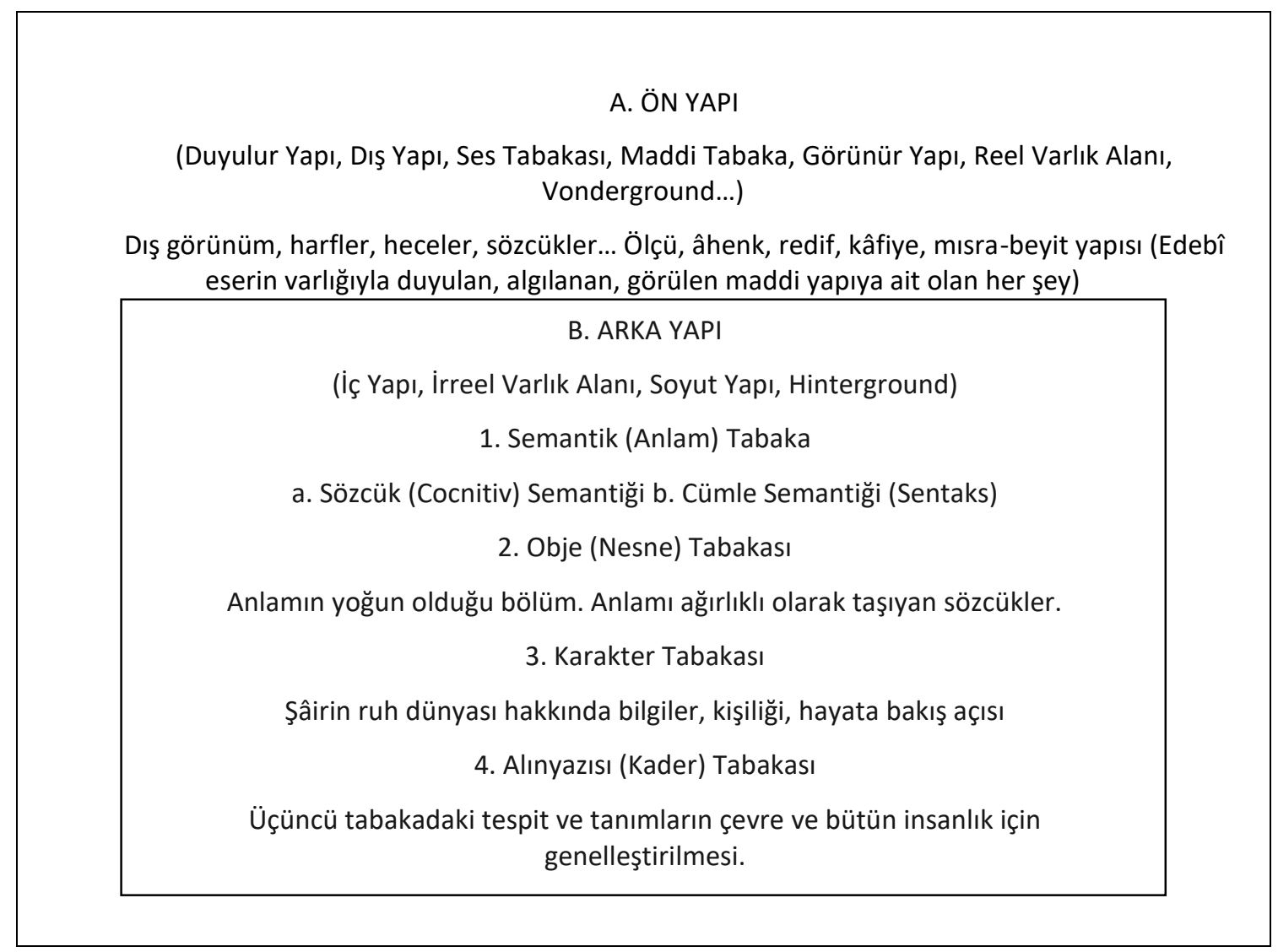

Tabloda belirtilen tabakalar şu şekilde açıklanabilir:

\section{A. Ön Yapı}

Ön yapı, edebî eserin dış yapısıdır. Yani bir şiir için ses, sözcük ve sözcük grubu tekrarları, kafiye, ölçü vb. dir. Ön yapının incelenmesindeki amaç, edebî eserin duyulur veya görünür özelliklerini keşfetmektir. Bu özellikleri keşfetmek eserin derin yapısında saklı olan anlama en doğru şekilde ulaşmada büyük bir kolaylık sağlar. Ön yapıya diğer bir ifadeyle dış tabaka veya ses tabakası denilmektedir.

Duyulur Yapı/Ses Tabakası: Bilindiği üzere edebiyat sanatı dil ile kurulan, dile dayanan bir sanattır. Bütün edebî türler sözcüklerle oluşur. Sözcük, edebiyat sanatının dayandığı ana temeldir. Sözcükte ise bir yandan bir ses, bir yandan da bir anlam vardır (Tunalı, 2011: 80). Bu iki unsur arasında sıkı bir ilişki bulunur. Ses tabakasında temelde bu ilişki üzerinde durulur. 
Bu tabakada, ontolojik özelliklerle birlikte estetik özellikler de ön plana çıkar. Ses tabakasının anlam tabakasının taşıyıcısı olduğu düşüncesi genel kabul görmekle beraber eksik bir düşüncedir. Çünkü “iyi yazılmış bir şiirde kelimelerin sesleriyle manaları arasında sıkı bir bağ vardır" (Wellek ve Warren, 1983: 230). Roman Ingarden'a göre ses tabakasının ya da materyalinin ortadan kalkmasıyla, anlam birlikleri tabakası da varlığını kaybeder ve onunla birlikte, edebiyat eserinin diğer tabakaları da ortadan kalkar (Tunalı, 2011: 81). Kısacası sözcüklerdeki ses değerleri şiirdeki anlamı görünür kılmada çok etkilidir. Bu tabakada şiirde tercih edilen sözcükler üzerinde ses özellikleri bakımından dikkatle durulur ve şiirin ses haritası çıkarılmaya çalışılır (Köktürk, 2003: 173).

\section{B. Arka Yapı}

Edebî eserlerin, varlık tarzı bakımından bir reel, duyusal tabaka (ön yapı) ile bir duyuüstü, irreel tabakadan (arka yapı) meydana geldiği söylenmişti. Bu iki tabaka arasındaki tek ilişki şekli ise irreel'in reel'de görünüşe ulaşmasıdır. Sanat eserinin ontik bir zaruret olarak meydana gelebilmesi için arka yapının ön yapıda görünüşe çıkması gereklidir. Öte yandan ön yapı da aynı zorunlulukla arka yapıyı, tabakalar sırasına göre aşağıdan yukarıya doğru göstermelidir. Ön yapı ile arka yapının bu münasebetinde irreel'in reel'de görünüşe ulaşması, aydınlanması, gizlide bulunan anlam dünyasının ışıklanışı, reel içinde somutlaşması, irreelite ve reelitenin, bu iki ayrı ve zıt dünyanın bir çeşit kucaklaşışı demektir (Tunalı, 2011: 21). Yani ön yapı ile arka yapı, bir kâğıdın iki yüzü gibidirler. Birbirlerinden ayrı olarak değerlendirilemez.

1. Semantik Tabaka: Bu tabakada tek tek sözcüklerin anlamından hareketle cümlelerin anlamları analiz edilir. Diğer bir ifadeyle göstergelerin tek tek anlamından ziyade birim anlamlarından saparak metin içinde birliktelikten doğan anlamları üzerine yoğunlaşılır. Çünkü sanat düzeyine çıkmış hiçbir edebî eser birincil anlamla yetinilecek kadar fakir değildir. Aksine "şiirin birincil anlamı asıl anlatılmak isteneni taşıyan hamal" durumundadır (Tökel, 2003: 39-43).

a. Sözcük (Cocnitiv) Semantiği: Sözcükler tek tek ele alınır ve öncelikle yapı olarak sorgulanır. Daha doğrusu anlam çalışması yaparken sözcüklerin sesi ve görüntüsü göz önünde bulundurulur. Söz konusu edilen metin bir şiirse sözcüklerin yapılarından hareketle derin yapıda çağrıştırdıkları anlamlar sorgulanır. Bu anlamda özellikle imge hâline bürünmüş sözcükler üzerinde durulur.

b. Cümle Semantiği (Sentaks): Edebî eseri oluşturan cümleler anlam açısından değerlendirilir. Sözcük çalışmalarında olduğu gibi cümle semantiğinde de önemli olan cümleyi oluşturan sözcükleri cümledeki bağlam dâhilinde ele almak ve cümlenin ifade ettiği potansiyel anlamı bulmaktır. Yani burada da anlam kadar yapı da önemlidir. Literatürde genelde anlam üzerine yoğunlaşılmıştır. Ancak ontolojik estetikte anlamı görünür kılan dış yapıdır, dolayısıyla cümleyi anlam olarak şiir içerisinde doğru konumlandırabilmek için cümleyi görünür kılan yapılar da çözümlenmelidir.

2. Obje (Nesne) Tabakası: Bu tabakada nesnelerin derin yapılarına inilmeye çalışılır. Bu tabaka objeksiyon (Aydan bahsediliyorsa ay olduğu gibidir. Çağrışımlara kapalıdır.) ve objektivasyonun (Burada aya benzetilmek istenen şey somutlaştırılıp ay hâline getirilir) en net ayrıştığı tabakadır. Gösterilemeyen, soyut olan ya da anlatımında güçlük çekilen duygu, his, düşünce tabiattaki varlıklara yüklenerek bilinebilir bir obje hâline getirilir (İçli, 2008: 103).

3. Karakter Tabakası: En yalın ifadeyle edebî eserdeki kişilerin ruh ve düşünce dünyalarının sorgulandığı tabakadır. Eserin derin yapısındaki anlam ile eser kişisinin ilişkisi incelenir. Bu tabakada eser kişisinin yaklaşım tarzı önemlidir. Çünkü alımlayıcı olan suje, olayları ve objeleri eser kişisinin bilinciyle anlamlandırır. Bu sebeple karakter tabakasında eser kişisinin bakış açısı incelemelerin temelini oluşturur.

4. Alınyazısı (Kader) Tabakası: Bu tabaka varlığın tinsel tabakasıdır. Temelde sanat eserinde var olan her şeyin ilk hâli sorgulanır. Tinsel alanda bulunan nesneler kutsal, kolay ulaşılamayan ve değer verilen varlıklar oldukları gibi, bu tabaka da edebî eserlerin bel kemiğidir. Aslında bahsedilen tüm tabakaların amacı eserin derininde yatan öze ulaşmaktır. Bu sebeple kutsal sayılan düşünceler bu tabakada bulunur. Buna kader tabakası denilmesi de bu özelliği barındırdığı içindir. Yani her durumda bu tabakayı keşfetmek demek eserin kaderini okumaktır (Kardaş, 2014: 527; İçli, 2008: 103; Köktürk, 2003: 173).

\section{ilgili Araştırmalar}

Türkçenin öğretiminde şiirin yeri ve şiir öğretiminin temel dil becerilerinin geliştirilmesine katkısı üzerine çalışmaların yeterli olmadığını söylemek gerekir. Literatürde şiir kuramı ve tahlili ile ilgili çokça çalışmaya rastlamak zor değilken aynı çeşitliliğin şiir öğretiminde olduğu söylenemez. Karadeniz (2012), modern metin çözümleme metotlarının lisans öğrencilerinin şiir çözümleme becerilerine etkisini incelemiş ve söz konusu yaklaşımların etkili olduğunu, şiir öğretiminde kullanılabileceğini tespit etmiştir. Yıldırım (2012), şiirin Türkçe eğitimindeki yerini ve ikinci kademe Türkçe ders kitaplarındaki şiirleri incelediği çalışmasında, şiirin hangi açıdan Türkçe öğretiminde önemli olduğunu somut örneklerle göstermiştir.

Şiir okumanın Türkçenin öğretiminde ne derece etkili olduğunu sorgulayan Demir ve Duman (2004), şiirin kuramsal zeminini anlatmış ve şiir okuma tekniklerini ifade ederek şiir okumanın öğrencilerin iç dünyalarını 
geliştirdiğini, okuma ve yazma konusunda onları rahatlattığını, onlara okumayı sevdirdiğini ifade etmişlerdir. Şiirin okuma ve yazma öğretimindeki önemi üzerinde duran bir başka çalışma Kaya (2013) tarafından yapılmıştır. Kaya, şiirin; dili, düşünceyi, eleştirel düşünmeyi, yaratıcılığı, duyuları, duyguları, müzik ve ritmi aynı anda etkili bir şekilde bir araya getirdiği için yazma öğretiminin başarısındaki rolünün büyük olduğunu belirtmiş ve şiir metinleri kullanarak sınıf içinde uygulanması amacıyla etkinlik önerilerinde bulunmuştur. Kıbrıs (2008), öğrencilerin yazılı ve sözlü anlatım becerilerinin geliştirilmesinde farklı şiirlerin kullanılması gerektiği üzerinde durmuştur. Güney (2016) yazma eğitimi ile ilgili öğretmenlerin görüşlerine başvurduğu eserde, öğretmenlerin yazma becerisinin kazanımında şiir kullanımına dikkat çektiklerini söylemiştir.

Kurudayıoğlu (2003), öğrencilerin konuşma becerilerinin geliştirilmesi için derslerde kısa süreli şiir dinletileri, şiir canlandırmaları, söz korosu ile şiir okuma gibi etkinliklerin yapılması gerektiğini ifade etmiştir. Bu doğrultuda Uçgun (2013), öğrencilerin ders motivasyonlarını artırmak; yazma, konuşma ve dinleme becerilerini daha iyi bir seviyeye çıkarmak için şiirin kullanımının önemli olduğunu teorik temeller üzerinde belirtmiştir.

Şiir öğretiminde fonetik ve semantik ilişkisini ele alan Açık Önkaş (2010), fonetik-semantik ilişkili şiir inceleme yaklaşımı ile yetişen öğrencilerin, ses değerlerinin şiirlerin anlam evrenine katkısını kavrayarak onların duygusuna uygun okuma yapabildiklerini ileri sürmüştür. Bizzaro (1993), öğrencilerin şiir nedir ve nasıl yazılır sorularına feminist eleştiri, yeni eleştiri gibi modern eleştiri kuramlarından hareketle cevap vermiş ve okur, yazar, editör açısından şiirin ne olduğu ile ilgili geniş bir değerlendirme yapmıştır.

Şiir yazma konusuyla ilgili bir başka çalışmayı Esbensen (1975) yapmıştır. Esbensen, on beş bölümden oluşan eserinde öğrencilere şiir yazmanın hem kuramsal hem uygulama boyutunu tanıtmış ve farklı konularda şiir örnekleri sunmuştur. Hunley (2007) de modern yaklaşımlarla şiir yazma amaçlı hazırladığı çalışmasında, teorik olarak şiirin ne olduğu ve nasıl yazılabileceğini tartışmıştır. Tsujimato (1988), yedinci ve sekizinci sınıf öğrencilerine şiir öğretimi amaçlı model önersinde bulunmuş, şiir ile ilgili teorik bilgiler vermiş ve şiir örnekleri üzerinde durmuştur.

Öğrencilerin şiirlerinin nasıl değerlendirileceği ile ilgili çalışma yapan Collom (1985); okullarda şiir öğretimi, farklı temaları kullanarak şiir yazma, öğrenci şiirlerinin değerlendirilmesindeki ölçütler üzerinde durmuştur. Bizzaro (1990) da öğrenci şiirlerinin değerlendirilmesi ile ilgili bir model geliştirmiştir. Spiro (2007) ise şiir öğretimi ve şiir yazma konusunu üzerinde durmuş, şiir yazma serüvenini öğretim amaçlı olarak tüm boyutlarıyla gözler önüne sermiştir. Cahnmann (2003), şiirin eğitimdeki yerini tartışmış, dil öğretimi ile ilgili geliştirilen modern yaklaşımların şiiri önemsediğini ifade etmiştir. Smith (1985), şiir öğretimi ile ilgili ilkokul öğretmenlerinin kullanabileceği bir el kitabı yayınlamıştır. Smith, bu çalışmayla öğrencilerin okuma becerlerinin ve dili kullanabilme yeterliliklerinin geliştirilmesini amaçlamıştır.

İşbirlikli öğrenmenin şiir öğretimine etkisini araştıran Chemwei, Kiboss ve Ilieva (2005); işbirlikli öğrenmenin öğrencilerin akademik başarılarını artırdığı sonucuna ulaşmışlardır. İlkokulda şiir öğretimi konusunu ele alan Carter (2012); şiirin öğrencilerin dinleme, konuşma ve okuma becerilerinin geliştirilmesindeki yeri, öğrencilerin yazdıkları şiirlerin değerlendirilmesi, şiir öğretiminde uygulanabilecek etkinlikler gibi birçok hususa değinmiştir. Sınıflarda kullanmak üzere şiir etkinlik önerilerinde bulunan ve sınıf içi şiir çalışmalarına değinen bir diğer araştırmacı ise Harmer'dır (2000).

Edebî eserlerin çözümlenmesinde ontolojik metin analizi yöntemi son yıllarda kullanılan bir metot olmuştur. Ancak bu yöntem henüz şiir öğretiminde kullanılmamaktadır. Tabii ki bu yöntemin öğretim tekniği olarak kullanılabilmesi öncelikle bu yöntemle ilgili bilimsel araştırmaların yapılmasına, sonuçların paylaşılmasına bağlıdır. Bu doğrultuda literatüre bakıldığında hiçbir çalışmanın olmadığı görülmektedir. Alanda yapılan diğer çalışmalara bakıldığında ise bu yöntemin bazı şiirlere uygulandığı sonucunu ortaya koymaktadır. Köktürk (2003), Bayburtlu Zihnî̀nin bir koşmasını ontolojik yöntemle incelemiş ve sonuç olarak söz konusu koşmanın estetik bir değer taşıdığını ifade etmiştir. İçli (2008), Necati'nin bir şiirini bu yöntemle analiz etmiştir. Kardaş (2014), aynı yöntemle Nâbî'nin "Gelür Gider" redifli gazelini yorumlamıştır. Öcal (2008) ise Ataol Behramoğlu'nun "Yaşadıklarımdan Öğrendiğim Bir Şey Var" adlı şiirini tahlil etmiştir. Aykanat (2013), Şeyh Gâlib'in bir gazeline ontolojik çözümlemeyi temele alarak yapısalcı bakış açısıyla yaklaşmıştır. Gürbüz (2014), Tevfik Fikret'in "Ramazan Sadakası" adlı şiirini ontolojik metodla çözümlemiş, şiirin ritmini sağlayan aliterasyon, asonans, kafiye, redif, söz sanatları gibi armonik unsurların şiirin anlam tabakasına olan katkısını ortaya çıkarmış, tabakalardan hareket ederek şiirin temasına ulaşmaya çalışmıştır. Issı (2004), “Turgut Uyar’ın “Göğe Bakma Durağı” Şiirinde Tema'ya (Matris) Ulaşma Serüveninin 'Ontolojik Analiz Metodu'yla Takibi” adlı makalesinde Roman İngarden'in sistemleştirdiği ontolojik yaklaşım biçimini Turgut Uyar’ın şiirine uygulamış, bu çerçevede şiirin temasına ulaşmaya çalışmıştır. Hazer (2014), “Ontolojik Tahlil Metoduyla Ahmet Muhip Dıranas'ın 'Yaşarken' Şiirinin Incelenmesi” adlı araştırmasında ontolojik 
analiz metodunu kullanarak söz konusu şiiri çözümlemiştir. Demircan (2014), "Necip Fazıl'ın "Karacaahmet" Şiirine Ontolojik Bir Yaklaşım Denemesi" başıklı yazısında yine ontolojik metotla bir tahlil denemesinde bulunmuştur. Aynı yöntemle Necip Fazıl'ın "Ben" şiirini inceleyen Altunkaya (2013), şiiri ses ve sözcük, cümle ve anlam, karakter ve ruh ile alınyazısı tabakalarını tek tek açarak çözümlemiş, eserin estetik değerini ortaya koymaya çalışmıştır. Bu çalışmalara ek olarak Sarıçiçek (2009), Sarıçiçek (2008), Taşkesen (2015) ve Deger'in (2015) de ontolojik analiz metodunu kullanarak metin tahlili yaptıkları görülmüştür.

Literatür genel anlamda değerlendirilecek olursa son dönemlerde modern yaklaşımların dil öğretiminde kullanımı ile ilgili çalışmaların yapıldığı görülmektedir. Ancak hâlihazırdaki çalışmaların alandaki ihtiyaca cevap verecek çeşitlikte olduğunu söylemek mümkün değildir. Aynı şekilde okuma anlama hususunda son yıllarda çalışmaların sayısının arttığı söylenebilir. Bunlara ek olarak modern metin çözümleme yaklaşımlarının okuma anlama becerilerinin geliştirilmesindeki yeri araştırılmaya muhtaç konu olarak durmaktadır. Bu çalışmanın konusu ile ilgili olan asıl alan ise şiir öğretimidir. Şiir ve şiir öğretimi ile ilgili kuramsal anlamda çok sayıda çalışmaya rastlanmıştır. Ancak şiir öğretimi hakkında özellikle ulusal literatürde çok az çalışmanın olduğunu söylemek gerekir. Yabancı literatürde şiir öğretiminin çok önemsendiği ve araştırmacıların şiirin öğretimi ile ilgili farklı seviyelerde ve alanlarda çalışmalar ortaya koydukları tespit edilmiştir. Ulusal literatürde şiir öğretimi ile ilgili sınıf içi etkinlikler; öğrencilerin şiir çözümleme, okuma ve yazma becerilerinin geliştirilmesi, şiir öğretiminde modern yaklaşımların yeri, önemi ve etkisi; şiir öğretiminin kuramsal temelleri gibi birçok konu ele alınabilir. Bu gerekçeyle bu çalışmada ortaokul yedinci sınıf öğrencilerinin şiir çözümleme başarılarının artııımasında etkinliklere dayalı ontolojik metin analizi yönteminin etkisini ortaya koymak amaçlanmıştır. Bu amaçla araştırmada "Etkinliklere dayalı ontolojik metin analizi yöntemi, ortaokul yedinci sınıf öğrencilerinin şiir çözümleme başarılarının artırılmasında etkili midir?" sorusuna cevap aranmıştır.

\section{Yöntem}

\section{Araştırmanın Deseni}

Araştırma, ön test-son test kontrol gruplu deneysel desen olarak planlanmıştır. Bu desende öncelikle deney ve kontrol grupları belirlenir. Daha sonra iki grubun uygulama öncesinde bağımlı değişkenle ilgili ölçümleri alınır. Uygulama sürecinde ise etkisi test edilen deneysel işlem deney grubuna verilirken kontrol grubuna verilmez. Son olarak gruplardaki deneklerin bağımlı değişkene ait ölçümleri aynı araç ya da eş formu kullanılarak tekrar elde edilir. Deneysel işlemin etkisini görmek amacıyla deney ve kontrol gruplarının bağımlı değişkene ait ölçme sonuçları uygun teknikler kullanılarak değerlendirilir (Büyüköztürk, Kılıç Çakmak, Akgün, Karadeniz ve Demirel, 2009: 204, 205; Robson, 2015 : 127).

Ön test-son test kontrol gruplu deneysel desende olduğu gibi öncelikle deney ve kontrol grupları belirlenmiştir. Deney ve kontrol gruplarının uygulamanın başındaki şiir çözümleme başarılarını belirlemek amacıyla araştırmacı tarafından geliştirilen Şiir Çözümleme Formu (ŞÇF) uygulanmıştır. Daha sonra Meram Yayınları 7. sınıf Türkçe Ders Kitabı'nda yer alan şiirler ontolojik metin analizi yöntemi doğrultusunda değerlendirilmiş ve öğrencilerin düzeylerine göre etkinlikler tasarlanmıştır. Tasarlanan etkinlikler ders öğretmenleri tarafından bir ders yılı boyunca uygulanmıştır. Uygulama süreci sonunda yine deney ve kontrol gruplarının son test puanlarını tespit etmek amaçlı şçF kullanılmıştır. Bu deneysel süreç sonucunda ilgili formlardan elde edilen veriler analiz edilmiş ve yorumlanmıştır.

\section{Çalışma Grubu}

Çalışmanın grubu, aykırı durum örnekleme yöntemi ile belirlenmiştir. Bu örnekleme yönteminin incelenen problemle ilgili olarak var olan birbirine aykırı (uç) durumların, örneklerin araştırmacıya değişkenliği daha net görme olanağı vereceği kabul edilir. Araştırmada amaç, uçlarla ilgili olarak değişkenliğin doğasını genelleme kaygısı yaşamadan ayrıntılı olarak görmek ise, aykırı durum örnekleme iyi bir çözüm olabilir. Öğrenci performansını çeşitli boyutlarıyla inceleyerek başarı ve başarısızlık olgusunu anlamaya, açıklamaya çalışan bir araştırmacının, örneklemini amacına bağlı olarak öğrenci başarısının en yüksek ve en düşük olduğu okullardan seçmesi aykırı örnekleme bir örnektir (Büyüköztürk ve diğerleri, 2009: 90). Çalışmada söz konusu örnekleme yöntemiyle Erzurum il merkezinde bulunan sosyoekonomik seviye ve 2014 yılı TEOG başarı sıralaması açısından düşük dereceli bir ortaokul (O1) ile yüksek dereceli bir ortaokul (O2) olmak üzere iki okul seçilmiştir. Bu okullarda yapılacak olan çalışmalar hakkında Türkçe öğretmenlerine bilgi verilmiş ve gönüllü olan, aynı zamanda iki yedinci sınıfın da dersine giren öğretmenlere öncelik verilmiştir. Bu usulle her iki okulda da seçilen iki yedinci sınıf arasında kura çekimi yapılarak deney ve kontrol gruplarının belirlenmesi tamamlanmıştır. Çalışmaya 01 deney grubunda (D1) 9 kız, 8 erkek; kontrol grubunda (K1) 10 
kız, 7 erkek ve 02 deney grubunda (D2) 11 kız, 10 erkek; kontrol grubunda (K2) 7 kız, 14 erkek olmak üzere toplam 76 öğrenci katılmıştır.

Deney ve kontrol gruplarının denklikleri; 6. sınıftaki Türkçe dersi karne notları, Türkçe dersi ve şiir sevme durumları dikkate alınarak incelenmiştir. Deney ve kontrol gruplarının belirtilen değişkenler açısından denk olup olmadığını ortaya koymak için öncelikle verilerin normal dağılıp dağılmadığına bakılmıştır. Verilere ait Shapiro-Wilk testi, mod, medyan ve aritmetik ortalama ile basıklık ve çarpıklık katsayıları; Histogram Grafiği; Normal Q-Q Grafiği; Gövde Yaprak Diyagramı ve Kutu Grafiği değerlendirilmiş, normal bir dağılım olmadığı tespit edilmiştir. Diğer yandan Normallik Shapiro-Wilk testi sonuçları incelendiğinde anlamlılık değerlerinin ,05'ten küçük olduğu ve bu sonuçların da verilerin normal dağılmadığına işaret ettiği söylenebilir. Basıklık ve çarpıklık katsayılarının da normal dağılım aralığında olmadığı ve grafiklerde verilerin normal dağılıma sahip olmadığı görülmüştür. Verilerde normallik varsayımları karşılanmadığı için analizde parametrik olmayan Mann-Whitney U testi kullanılmıştır.

Tablo 1'de O1 D1 ve K1'de bulunan öğrencilerin akademik başarı, şiir sevme ve Türkçe dersini sevme açısından birbirlerine denk oldukları görülmektedir. Burada öğrencilerin altıncı sınıf Türkçe dersi yılsonu karne notlarına göre değerlendirme yapılmıştır.

Tablo 1. $\mathrm{O}_{1} \mathrm{D}_{1}$ ve $K_{1}$ Akademik Başarı Puanları, Şiir Sevme Durumları ve Türkçe Dersini Sevme Durumları ile ilgili Mann-Whitney U Testi Sonuçları

\begin{tabular}{|c|c|c|c|c|c|}
\hline \multicolumn{6}{|c|}{ Akademik Başarı Puanları } \\
\hline Gruplar & $\mathrm{n}$ & Ortalama & $\mathrm{U}$ & Z & $p$ \\
\hline Deney Grubu & 17 & 16,09 & \multirow{2}{*}{120,500} & \multirow{2}{*}{,- 851} & \multirow{2}{*}{,395 } \\
\hline Kontrol Grubu & 17 & 18,91 & & & \\
\hline \multicolumn{6}{|c|}{ Şiir Sevme Durumları } \\
\hline Deney Grubu & 17 & 17,12 & \multirow{2}{*}{138,000} & \multirow{2}{*}{,- 238} & \multirow{2}{*}{,812 } \\
\hline Kontrol Grubu & 17 & 17,88 & & & \\
\hline \multicolumn{6}{|c|}{ Türkçe Dersini Sevme Durumları } \\
\hline Deney Grubu & 17 & 15,97 & \multirow{2}{*}{118,500} & \multirow{2}{*}{,- 998} & \multirow{2}{*}{,318 } \\
\hline Kontrol Grubu & 17 & 19,03 & & & \\
\hline
\end{tabular}

Tabloda görüldüğü gibi D1 öğrencilerinin Türkçe dersi akademik başarı puanlarının aritmetik ortalaması 16,09, K1 öğrencilerinin puan ortalaması 18,91 olarak bulunmuştur. Bu verilere göre D1 ve K1'deki öğrencilerin akademik başarı puanları arasında anlamlı düzeyde farklılık olmadığı anlaşılmaktadır (U=120,500, Z=-,851, p>0,05). D1 öğrencilerinin şiir sevme durumlarını gösteren puanların aritmetik ortalamasının 17,12, K1 öğrencilerinin puan ortalamasının ise 17,88 olduğu görülmektedir. Bu değerler D1 ve K1'deki öğrencilerin şiir sevme durumlarını gösteren puanlar arasında anlamlı düzeyde farklılık olmadığı sonucunu doğurmaktadır (U=138,000, Z=-,238, p>0,05). Tabloya bakıldığında D1 öğrencilerinin Türkçe dersini sevme durumlarını gösteren puanların aritmetik ortalamasının 15,97, K1 öğrencilerinin puan ortalamasının ise 19,03 olduğu ortaya çıkmaktadır. Bu bilgiler, D1 ve K1'deki öğrencilerin Türkçe dersi sevme durumlarını gösteren puanlar arasında anlamlı düzeyde farklılık olmadığını göstermektedir $(U=118,500, Z=-, 998$, $p>0,05)$.

Tablo 2'de O2 D2 ve K2'de bulunan öğrencilerin akademik başarı, şiir sevme ve Türkçe dersini sevme açısından birbirlerine eşit olup olmadığı ile ilgili veriler yer almaktadır.

Tablo 2. O2 D2 ve K2'nin Akademik Başarı Puanlarının Mann-Whitney U Testi Sonuçları

\begin{tabular}{|c|c|c|c|c|c|}
\hline \multicolumn{6}{|c|}{ Akademik Başarı Puanları } \\
\hline Gruplar & $\mathrm{n}$ & Ortalama & $\mathrm{U}$ & Z & $p$ \\
\hline Deney Grubu & 21 & 24,07 & \multirow{2}{*}{166,500} & \multirow{2}{*}{$-1,505$} & \multirow{2}{*}{ 132 } \\
\hline Kontrol Grubu & 21 & 18,3 & & & \\
\hline \multicolumn{6}{|c|}{ Şiir Sevme Durumları } \\
\hline Deney Grubu & 21 & 20,45 & \multirow{2}{*}{198,500} & \multirow{2}{*}{,- 602} & \multirow{2}{*}{,547 } \\
\hline Kontrol Grubu & 21 & 22,55 & & & \\
\hline \multicolumn{6}{|c|}{ Türkçe Dersini Sevme Durumları } \\
\hline Deney Grubu & 21 & 21,67 & \multirow{2}{*}{217,000} & \multirow{2}{*}{,- 107} & \multirow{2}{*}{ 915 } \\
\hline Kontrol Grubu & 21 & 21,33 & & & \\
\hline
\end{tabular}

Tabloda görüldüğü gibi D2 öğrencilerinin Türkçe dersi akademik başarı puanlarının aritmetik ortalaması 24,07, K2 öğrencilerinin puan ortalaması 18,93 olarak bulunmuştur. Bu verilere göre O2 D2 ve K2'deki öğrencilerin akademik 
başarı puanları arasında anlamlı düzeyde farklılık olmadığı anlaşılmaktadır ( $U=166,500, Z=-1,505, p>0,05)$. Tablodaki değerler irdelendiğinde D2 öğrencilerinin şiir sevme durumlarını gösteren puanların aritmetik ortalamasının 20,45, K2 öğrencilerinin puan ortalamasının 22,55 olduğu tespit edilmektedir. Buna göre D2 ve K2'deki öğrencilerin şiir sevme düzeyleri ile ilgili puanlar arasında anlamlı düzeyde farklılık olmadığı anlaşılmaktadır ( $U=198,500, Z=-, 602, p>0,05)$. Tabloda görüldüğü gibi D2 öğrencilerinin Türkçe dersini sevme durumlarını gösteren puanların aritmetik ortalaması 21,67, K2 öğrencilerinin ortalaması ise 21,33'tür. Bu bilgilere göre bir değerlendirme yapılacak olursa D2 ve K2'deki öğrencilerin Türkçe dersi sevme düzeylerini gösteren puanlar arasında anlamlı bir farklılı̆ın bulunmadığı söylenebilir $(U=217,000, Z=-, 107, p>0,05)$. Bu veriler her iki okuldaki grupların uygulama öncesinde denk olduklarını göstermektedir.

\section{Veri Toplama Araçları ve Analizi}

\section{Ontolojik Metin Analizi Etkinlikleri (OMAE)}

Araştırmanın uygulama aşamasında kullanmak üzere ontolojik metin analizi temelli etkinlikler hazırlanmıştır. Bu etkinlikler tasarlanırken yedinci sınıf öğrencilerinin bilişsel ve duyuşsal seviyeleri dikkate alınmıştır.

Ontolojik Metin Analizi Etkinlikleri'nin hazırlanmasında metot olarak ontolojik metin analizi yöntemi kullanılmıştır. Ontolojik metin analizi yöntemi; "ses tabakası", "anlam birimleri tabakası", "nesne ve karakter tabakası" ve "kader tabakası" şeklinde olmak üzere dört tabakaya dayanmaktadır. Etkinlikler tasarlanırken temelde bu tabakalar dikkate alınmıştır.

İlk etkinlikler vurgu ve tonlamaya dikkat ederek okuma çalışması yapma amaçlı tasarlanmış, okuma etkinliklerinden sonra şiirin dış yapısıyla ilgili etkinliklere geçilmiş ve öğrencilerin şiirin dış yapısıyla ilgili tespitler yapmalarını sağlayacak (şiirdeki cümleleri bulma, tamlamaları bulma, sözcüklerle ilgili olumlu-olumsuz, soyut-somut, mecaz anlam-gerçek anlam gibi sınıflandırmalar yapma, şiirin anlamı açısından önemli olan sesleri bulma, sesler üzerinden çıkarımlar yapma, kullanılan eklerin şiiirin anlamı açısından neler ifade ettiği vb.) etkinlikler oluşturulmuştur.

Literatürdeki çalışmalarda ele alınan şiirin ses tabakası ile ilgili ortaya konulan bulgularda sadece ses unsurları üzerinde durulduğu tespit edilmiştir. Cümle ve tamlamalar hakkında incelemelere yer verilmediği anlaşılmıştır. Bu noktada uzman görüşleri ve araştırmacının incelemeleri sonucunda farklı bir yol denenmiş ve öncelikle anlam birliklerinin keşfinin daha öğretici bir usul olabileceği görülmüştür. Bu sebeple ilk olarak okuma çalışmaları yapılmış, ses haritası etkinliklerine yer verilmiş ve anlam tabakası ile ilgili incelemelerin başında cümle ve tamlama çalışmaları gerçekleştirilmiştir.

Ontolojik metin analizi yönteminin bir sonraki tabakasında şiirde geçen imgeler, metaforlar, çağrışım alanı geniş olan yapılar üzerinden üst yorumlara gitmek amaçlanır. Bu tabaka ile ilgili yapılan etkinliklerde ise şiirin anlamı açısından önemli olan ve imge değeri taşıyan sözcük ve sözcük grupları ön plana çıkarılmış ve öğrencilerin bu sözcüklerle ilgili yazılı ve sözlü olarak fikirlerini ifade etmeleri sağlanmıştır. Tüm bu uygulamalar yapılırken öğrencilerin şiirdeki bağlamdan kopmamaları gözetilmiştir.

Ontolojik metin analizi yöntemiyle ilgili alanda yapılan çalışmalarda nesne ve karakter tabakasında şiirin şairinin kimliğinin sorgulandığı ve o noktadan şiire yaklaşıldığı görülmektedir. Bu çalışmada karakter tabakası dâhilinde düzenlenen etkinliklerde şairin hayatından şiire yaklaşmak yerine şiire yansımış olan 'ben'in nasıl olduğuna yoğunlaşılmıştır. Yani şiirdeki 'ben'in nasıl biri olduğu sorusu öğrencilere sorulmuş, bu 'ben'i kendileriyle kıyaslamaları ve o doğrultuda değerlendirmelerini yazılı olarak ifade etmeleri istenmiştir. Bunun yanında bazı şiirlerde nesnelerin de bir karakter olarak sunulduğu düşünüldüğünde, söz konusu nesnelerle ilgili öğrencileri düşündürmeye yönelik etkinliklere de yer verilmiştir.

Kader (alın yazısı) tabakasıyla ilgili düzenlenen etkinliklerde ise temel nokta şiirde verilmek istenen ve bütün insanlık için geçerli olan evrensel düşünce sorgulanmıştır. Öğrencilerin şiirden anladıklarını kendi hayatlarıyla ilişkilendirmelerini veya şiirden çıkardıkları anlamla hayat arasında ilişki kurmalarını sağlayacak etkinlikler düzenlenmiştir. Mesela üzerinde durulan şiirdeki 'ben' deniz hasreti çekiyorsa öğrencilere "Sizce şiirdeki kişi ile deniz arasında nasıl bir bağ vardır? Şiirden hareketle deniz ile insanoğlunun ilişkisini tanımlayınız." şeklinde sorulardan oluşan etkinlikler tasarlanmıştır.

Etkinlikleri içeren yönergenin oluşturulmasında ise şu işlem basamakları takip edilmiştir:

1. Ontolojik metin analizi yönteminin şiiri ele alış tarzı literatürden ve sanat ontolojisinin kuramsal altyapısından hareketle anlaşılmaya çalışılmıs ve bu yöntemin şiir öğretiminde etkinlik hâline getirilmesi üzerinde durulmuştur.

2. Ahmet Hamdi Tanpınar'ın "Selâm Olsun" adlı şiiri seçilerek bir taslak yönerge hazırlanmış ve şiir öğretimi alanında uzman üç araştırmacının görüşüne başvurulmuştur. Uzmanların görüşleri doğrultusunda pilot uygulamada kullanmak üzere yönergeye son şekli verilmiştir. 
3. Bu yönergedeki hususlar gözetilerek aynı şekilde Cahit Sıtkı Tarancı'nın “Memleket İsterim” ve Ömer Bedrettin Uşaklı'nın "Deniz Hasreti” şiiriyle ilgili iki yönerge daha hazırlanmıştır.

4. Hazırlanan yönergeler 2014-2015 eğitim öğretim yılında Erzurum il merkezindeki sosyoekonomik ve akademik başarı açısından orta düzeyli bir ortaokulun kolay ulaşılabilir örnekleme yöntemi ile seçilen bir yedinci sınıfında üç hafta boyunca araştırmacı tarafından uygulanmıştır.

5. Pilot uygulamanın sonunda öğrencilerden uygulama süreci, yöntem ve etkinlikler hakkında görüş alınmıştır. Bu görüşler ve araştırmacının üç hafta boyunca derslerde yaptığı gözlemler esas uygulama sürecinde gerçekleştirilecek etkinliklere ışık tutmuştur.

6. Araştırmanın asıl uygulamasında kullanılacak şiirler ile ilgili yapılan çalışmalar, hem okullardaki programı aksatmamak adına hem de deney ve kontrol grupları arasında geçerli bir değerlendirme yapmak amacıyla uzman görüşlerinin de etkisiyle ders kitaplarındaki şiirlerin seçimiyle sonuçlanmıştır. Bu sebeple etkinliklerde Meram Yayınları Yedinci Sınıf Türkçe Ders Kitabı'nda bulunan şu yedi şiir kullanılmıştır: Arif Nihat Asya'nın "Bayrak", Rıza Tevfik Bölükbaşı'nın "Uçun Kuşlar", Turgut Uyar'ın "Gazi Paşa'ya Ağıt", Karacaoğlan'ın "Koşma”, Âşık Veysel Şatıroğlu'nun "Dostlar Beni Hatırlasın”, Attilâ ilhan'ın "Cazgır", Talip Apaydın'ın "Isıtan Güneşe Şiir" adlı şiiri.

7. Asıl uygulamada kullanılacak etkinliklerin oluşturulmasında pilot uygulamadaki öğrenci görüşleri ve araştırmacının gözlemi etkili olmuştur. Sonraki haftalarda hazırlanan etkinliklerde ders öğretmenlerinin görüşleri ve araştırmacının her iki okulda da yaptığı gözlemleri de sürece dâhil edilmiştir.

\section{Şiir Çözümleme Formu (ŞÇF) ve analizi}

Öğrencilerin uygulamanın başındaki ve sonundaki şiir çözümleme başarı durumlarını tespit etmek amacıyla araştırmacı tarafından "Şiir Çözümleme Formu (ŞÇF)" geliştirilmiştir. Form geliştirilirken ontolojik metin analizi yönteminin tabakaları dikkate alınmış ancak formdaki soruların öğrencilerin bilgi ve kavrama düzeyindeki zihinsel becerilerine uygun olmasına dikkat edilmiştir. Formda öncelikle cinsiyet, Türkçe dersi akademik başarı, şiir sevme, Türkçe dersini sevme gibi değişkenlere yer verilmiştir. Metin olarak ise Faruk Nafiz Çamlıbel'in "Çoban Çeşmesi" şiiri tercih edilmiştir. Bu şiir, araştırmacı tarafından belirlenen on şiir içinden çocuk edebiyatı alanında uzman iki araştırmacının görüşü sonucunda seçilmiştir (Araştırmacı şiirlerin seçiminde Baş (2015: 100), Yılar ve Celepoğlu (2013: 37-66), Yardımcı ve Tuncer (2012: 188, 189), Karatay'ın (2011: 77-123) düşüncelerine başvurmuştur.).

ŞÇF hazırlanırken şu adımlar takip edilmiştir:

1. Yukarıda belirtilen gerekçe ile formda kullanmak üzere "Çoban Çeşmesi" adlı şiir seçilmiştir.

2. Seçilen şiirle ilgili ontolojik metin analizinin tabakaları doğrultusunda formda 7 tane açık uçlu soruya yer verilmiş ve araştırmacı tarafından taslak bir form geliştirilmiştir.

3. Taslak form ile ilgili şiir öğretimi alanında 3, eğitim bilimleri alanında ise 2 uzmanın görüşüne başvurulmuştur.

4. Uzman görüşleri dikkate alınarak taslak formdaki soru sayısı 6’ya indirilmiştir.

5. Hazırlanan form öncelikle farklı bir yedinci sınıftaki üç öğrenciye uygulanmış, öğrencilerin soruları anlama durumlarından hareketle formdaki soruların anlaşılabilirliği kontrol edilmiştir.

6. Sorular öğrencilerin görüşleri doğrultusunda gözden geçirilmiş ve forma son şekli verilmiştir.

ŞÇF'den elde edilen verilerin analizinde ise şu işlemler gerçekleştirilmiştir:

1. Öncelikle araştırmacı tarafından cevap anahtarı hazırlanmış ve cevap anahtarının kontrolü için alanda uzman iki araştırmacının görüşü alınarak cevap anahtarına son şekli verilmiştir.

2. Cevap anahtarı doğrultusunda ŞÇF'ler ilk olarak araştırmacı tarafından okunmuş ve 100 puan üzerinden derecelendirme yapılmıştır.

3. Formlar araştırmacı dışında alanda uzman iki araştırmacıya da okutulmuştur. Öğrencilerin analize dâhil edilen puanları üç araştırmacının verdiği puanların ortalaması alınarak belirlenmiştir.

4. Elde edilen nihai veriler araştırmanın sorularına göre deneysel süreç göz önüne alınarak çözümlenmiştir.

Bu aşamada öncelikle verilerin normal dağılıp dağılmadığı kontrol edilmiştir. Verilere ait Shapiro-Wilk testi; mod, medyan ve aritmetik ortalama ile basıklık ve çarpıklık katsayıları; Histogram; Normal Q-Q Grafiği; Eğimden Arındırılmış Normal Q-Q Grafiği; P-P Grafiği; Kutu Grafiği; Gövde Yaprak Diyagramı incelenmiş normal bir dağılım olmadığı sonucuna ulaşılmıştır. Shapiro-Wilk testi testi sonuçları incelendiğinde bazı değerlerin 05 'ten küçük, bazı değerlerin ise büyük olduğu görülmektedir. Aynı durum basıklık ve çarpıklık katsayıları için de geçerlidir. Bu değerler verilerin normal 
dağılımı hususunda kesin bir yargı ortaya koymada yeterli olmadığı için Histogram, Gövde Yaprak Diyagramı, Kutu Grafiği gibi birçok kaynak sorgulanarak bir karara varılması gerekir (Seçer, 2013: 25). Bu şekilde bütüncül bir değerlendirme sonucunda normallik varsayımları karşılanmadığı anlaşılmış ve verilerin analizinde parametrik olmayan Mann-Whitney U ve Wilcoxon testi kullanılmıştır.

Mann-Whitney $U$ testi, iki ilişkisiz örneklemden elde edilen puanların birbirlerinden anlamlı bir şekilde farklılık gösterip göstermediğini test eder. Başka bir anlatımla, iki ilişkisiz grubun, ilgilenilen değişken bakımından evrende benzer dağılımlara sahip olup olmadığını test eder (Büyüköztürk, 2004: 149). Bu test özellikle örneklem büyüklüğünün düşük olduğu deneysel araştırmalarda ve normallik varsayımının karşılanmadığı betimsel araştırmalarda sıklıkla kullanılmaktadır (Seçer, 2013: 161). Wilcoxon testi ise aynı gruba ait iki ölçüm arasında anlamlı farklıık olup olmadığını araştırmada kullanılır. Bu analiz için veriler aynı gruptan elde edilmelidir ve aynı gruba ait sadece iki ölçüm bulunmalıdır. Ayrıca Bağımlı Örneklemler için t-Testi'nin koşulları sağlanmadığında, yani verilerin normallik varsayımı sağlanmadığında kullanılır (Kilmen, 2015: 245).

Deney ve kontrol gruplarının başarı ortalamalarına göre yapılan Mann-Whitney $U$ ve Wilcoxon testi sonuçları ise $p<0,05$ anlamlılık düzeyine göre tablolarda gösterilmiştir.

\section{Bulgular}

Bu başlık dâhilinde O1 D1 ve K1, O2 D2 ve K2 öğrencilerinin Şiir Çözümleme Formu'ndan aldıkları puanlarla ilgili bulgular tablolar hâlinde sunulmuş ve gerekli değerlendirmeler yapılmıştır.

Tablo 4'te O1 D1 ve K1'de bulunan öğrencilerin şiir çözümleme başarılarına dair ön test sonuçları sunulmaktadır.

Tablo 3. 01 D1 ve K1 Öğrencilerinin Şiir Çözümleme Formu’na Verdikleri Cevaplara ilişkin Ön Test Puanları ile ilgili Mann Whitney U Testi Sonuçları

\begin{tabular}{cccccc}
\hline Gruplar & $\mathrm{n}$ & Sıra Ortalaması & Sıra Toplamı & $\mathrm{U}$ & $\mathrm{p}$ \\
\hline Deney Grubu & 17 & 20,29 & 345,000 & \multirow{2}{*}{97,000} & \multirow{2}{*}{101} \\
\hline Kontrol Grubu & 17 & 14,71 & 250,000 & & \\
\hline
\end{tabular}

Tabloda görüldüğü gibi D1 öğrencilerinin Şiir Çözümleme Formu ön test başarı puanlarının aritmetik ortalaması 20,29, K1 öğrencilerinin puan ortalaması ise 14,71 olarak bulunmuştur. Bu verilere göre O1 D1 ve K1'deki öğrencilerin ön test puanları arasında anlamlı düzeyde farklılık olmadığı anlaşılmaktadır ( $U=97,000, p=, 101)$. Bu sonuç O1 D1 ve K1 öğrencilerinin ön test şiir çözümleme başarıları arasında belirgin bir farklılığın olmadığını göstermektedir.

Tablo 4'te $\mathrm{O} 1 \mathrm{~K} 1$ 'de bulunan öğrencilerin Şiir Çözümleme Formu'ndan aldıkları ön test ve son test sonuçlarına dair bilgiler verilmiştir.

Tablo 4. 01 K1 Öğrencilerinin Şiir Çözümleme Formu'ndan Aldıkları Ön Test ve Son Test Puanları ile ilgili Wilcoxon Testi Sonuçları

\begin{tabular}{cccccc}
\hline & $\mathrm{n}$ & Sıra Ortalaması & Sıra Toplamı & $\mathrm{z}$ & $\mathrm{p}$ \\
\hline Negatif Sıra & 7 & 8,07 & 56,50 & & \multirow{2}{*}{551} \\
\cline { 1 - 4 } Pozitif Sıra & 9 & 8,83 & 79,50 &,- 596 & \\
\hline Eşit & 1 & & & & \\
\hline
\end{tabular}

Tablo 4'ten, 01 K1 öğrencilerinin Şiir Çözümleme Formu'ndan aldıkları ön test ve son test puanları arasında anlamlı farklılaşma olup olmadığını belirlemek amacıyla yapılan Wilcoxon işaretli sıralar testi sonucunda aradaki farkın anlamlı olmadığı anlaşılmaktadır $(z=-, 596, p=, 551)$. Puanların sıra ortalamaları ve sıra toplamları dikkate alındığında pozitif sıraların lehine, yani son test lehine bir farklılık olduğu görülse de bu fark bir anlam oluşturmamaktadır. Buna göre Meram Yayınları 7. Sınıf Türkçe Dersi Öğretmen Kılavuz Kitabı'nda uygulanan şiir çözümleme yaklaşımlarının yedinci sınıf öğrencilerinin şiir çözümleme başarılarını geliştirmede etkili olmadığı söylenebilir.

Tablo 5'te 01 D1 öğrencilerinin Şiir Çözümleme Formu'ndan aldıkları ön test ve son test sonuçları ile ilgili veriler sunulmuştur. 
Tablo 5. 01 D1 Öğrencilerinin Şiir Çözümleme Formu'ndan Aldıkları Ön Test ve Son Test Puanları ile ilgili Wilcoxon Testi Sonuçları

\begin{tabular}{cccccc}
\hline & $\mathrm{n}$ & Sıra Ortalaması & Sıra Toplamı & $\mathrm{z}$ & $\mathrm{p}$ \\
\hline Negatif Sıra & 2 & 3,25 & 6,50 & & \multirow{2}{*}{001} \\
\cline { 1 - 4 } Pozitif Sıra & 14 & 9,25 & 129,50 & & \\
\hline Eşit & 1 & & & & \\
\hline
\end{tabular}

Tablo 5'e göre 01 D1 öğrencilerinin Şiir Çözümleme Formu'ndan aldıkları ön test ve son test puanları arasında anlamlı değişim olup olmadığını tespit etmek için yapılan Wilcoxon işaretli sıralar testi sonucunda aradaki farkın anlamlı olduğu görülmektedir $(z=-3,181, p=, 001)$. Puanların sıra ortalamaları ve sıra toplamları göz önünde bulundurulduğunda pozitif sıraların lehine, daha açık bir ifadeyle son test lehine bir farklılık olduğu sonucu ortaya çıkmaktadır. Buradan hareketle OMAE temelli yürütülen deneysel sürecin yedinci sınıf öğrencilerinin şiir çözümleme başarılarını geliştirmede etkili olduğu ifade edilebilir.

Tablo 6'da O2 D2 ve K2 öğrencilerinin Şiir Çözümleme Formu'ndan aldıkları ön test puanlarına ilişkin bulgular sunulmaktadır.

Tablo 6. O2 D2 ve K2 Öğrencilerinin Şiir Çözümleme Formu’na Verdikleri Cevaplara ilişkin Ön Test Puanları ile ilgili Mann Whitney U Testi Sonuçları

\begin{tabular}{cccccc}
\hline Gruplar & $\mathrm{n}$ & Sira Ortalaması & Sira Toplamı & $\mathrm{U}$ & $\mathrm{p}$ \\
\hline Deney Grubu & 21 & 26,05 & 547,000 & \multirow{2}{*}{125,000} & \multirow{2}{*}{016} \\
\hline Kontrol Grubu & 21 & 16,95 & 356,000 & & \\
\hline
\end{tabular}

Tablo 6'ya göre D2 öğrencilerinin Şiir Çözümleme Formu ön test başarı puanlarının aritmetik ortalaması 26,05, K2 öğrencilerinin puan ortalamasının ise 16,95 olduğu anlaşılmaktadır. Bu veriler, O2 D2 ile K2' deki öğrencilerin ön test puanları arasında anlamlı düzeyde farklılık olduğunu göstermektedir $(U=125,000, p=, 016)$. Bu sonuç O2 D2 ve K2 öğrencilerinin ön test şiir çözümleme başarıları arasında belirgin bir farklılı̆ın olduğunu ortaya koymaktadır. Yani D2 ile K2'nin sıra ortalamaları arasında 9,1 puanlık farkın olduğu göz ardı edilmemelidir. Bu durum iki grup arasında tam belirgin olmasa da farklılı̆̆ın olduğunu göstermektedir.

O2 K2 öğrencilerinin Şiir Çözümleme Formu'ndan aldıkları ön test ve son test sonuçları ile ilgili veriler Tablo 7'de verilmiştir.

Tablo 7. 02 K2 Öğrencilerinin Şiir Çözümleme Formu’ndan Aldıkları Ön Test ve Son Test Puanları ile ilgili Wilcoxon Testi Sonuçları

\begin{tabular}{cccccc}
\hline & $\mathrm{n}$ & Sıra Ortalaması & Sıra Toplamı & $\mathrm{z}$ & $\mathrm{p}$ \\
\hline Negatif Sıra & 7 & 8,14 & 57,00 & & \multirow{2}{*}{569} \\
\cline { 1 - 4 } Pozitif Sıra & 9 & 8,78 & 79,00 &,- 569 & \\
\hline Eşit & 5 & & & & \\
\hline
\end{tabular}

Tablo 7'deki verilerden $\mathrm{O} 2$ K2 öğrencilerinin Şiir Çözümleme Formu'ndan aldıkları ön test ve son test puanları arasında anlamlı bir değişimin olup olmadığını ortaya koymak amacıyla yapılan Wilcoxon işaretli sıralar testi sonucunda aradaki farkın anlamlı olmadığı anlaşılmaktadır $(z=-, 596, p=, 569)$. Puanların sıra ortalamaları ve sıra toplamları dikkate alındığında pozitif sıraların lehine, yani son test lehine bir farklılık olduğu görülse de bu fark bir anlam oluşturmamaktadır. Bu duruma göre Meram Yayınları 7. Sınıf Türkçe Dersi Öğretmen Kılavuz Kitabı'nda uygulanan şiir çözümleme etkinliklerinin yedinci sınıf öğrencilerinin şiir çözümleme başarılarının geliştirilmesinde bir etkisinin olduğu söylenemez.

Tablo 8'de O2 D2 öğrencilerinin Şiir Çözümleme Formu'ndan aldıkları ön test ve son test sonuçları ile ilgili Wilcoxon testi sonuçları sunulmuştur. 
Tablo 8. 02 D2 Öğrencilerinin Şiir Çözümleme Formu’ndan Aldıkları Ön Test ve Son Test Puanları ile ilgili Wilcoxon Testi Sonuçları

\begin{tabular}{cccccc}
\hline & $\mathrm{n}$ & Sıra Ortalaması & Sıra Toplamı & $\mathrm{z}$ & $\mathrm{p}$ \\
\hline Negatif Sıra & 3 & 2,83 & 8,50 & & \multirow{2}{*}{000} \\
\cline { 1 - 4 } Pozitif Sıra & 18 & 12,36 & 222,50 & $-3,720$ & \\
\cline { 1 - 4 } & 0 & & & & \\
\hline
\end{tabular}

Tablo 9'a göre O2 D2 öğrencilerinin Şiir Çözümleme Formu'ndan aldıkları ön test ve son test puanları arasında anlamlı farklılaşma olup olmadığını belirlemek için yapılan Wilcoxon işaretli sıralar testi sonucunda aradaki farkın anlamlı olduğu görülmektedir $(z=-3,720, p=, 000)$. Puanların sıra ortalamaları ve sıra toplamları değerlendirildiğinde pozitif sıraların lehine, diğer bir ifadeyle son test lehine büyük bir farklılı̆ın olduğu dikkat çekmektedir. Buradan hareketle OMAE odaklı yürütülen uygulama sürecinin, yedinci sınıf öğrencilerinin şiir çözümleme başarılarını geliştirmede etkili bir yöntem olduğu ileri sürülebilir.

\section{Sonuçlar}

$\mathrm{O}_{1}$ ve $\mathrm{O}_{2}^{\prime}$ de Meram Yayınları 7. Sınıf Türkçe Dersi Öğretmen Kılavuz Kitabı'nda uygulanan şiir çözümleme yaklaşımlarının yedinci sınıf öğrencilerinin şiir çözümleme başarılarının artırılmasında etkili olmadı̆̆ı, OMAE temelli yürütülen deneysel sürecin ise 7. sınıf öğrencilerinin şiir çözümleme başarılarının artırılmasında etkili olduğu sonucuna ulaşılmıştır. Bu sonuç OMAE'nin şiir öğretiminde etkin bir araç olarak kullanılabileceğini göstermektedir. Çünkü OMAE, şiiri her yönüyle ele alma, değerlendirme, yorumlama ve çözümleme imkânı sunmaktadır. Öğrencilerin şiirin temel unsurlarını (kafiye, vezin, mısra, bent, dörtlük, tekrarlar vb.) keşfedebilmeleri, şiirdeki anlam birliklerini bulabilmeleri, şiirdeki imgeleri eleştirel bir dikkatle değerlendirebilmeleri, şiirin anlam dünyası içinde öneme sahip olan sözcükleri gerek anlam gerek yapı bakımından çözümleyebilmeleri OMAE ile daha mümkün hâle gelmektedir. OMAE şiirde var olan hiçbir ögenin rasgele olmadığı, muhakkak bir görevinin olduğu düşüncesinden hareket eder. Bu sebeple şiir öğretiminde, şiire ait olan ne varsa hepsini dikkate alır. Yani bu hususta öğreticilere geniş bir çalışma alanı sunmaktadır. Araştırmadan elde edilen bu sonuçla ilişkili olarak Karadeniz (2012), modern çözümleme yaklaşımlarının şiir çözümleme becerisine etkisini araştırdığı çalışmasında, modern çözümleme yaklaşımlarıyla şiir tahlili amaçlı etkinlikler tasarlamış ve Türkçe öğretmenliği lisans programı ikinci sınıf öğrencileri örnekleminde uygulama yapmıştır. Karadeniz, öğrencilerin şiir çözümleme becerilerinin geliştirilmesinde ontolojik metin analizi yönteminin de içinde olduğu modern çözümleme yaklaşımlarının etkili olduğunu ifade etmiştir.

$\mathrm{O}_{1}$ ve $\mathrm{O}_{2}^{\prime}$ de, yöntem bölümünde ifade edilen dikkatlerle hazırlanan etkinlikler uygulanırken öğrencilerin şiiri tüm bileşenleriyle değerlendirebilmeleri adına birçok etkinliğe yer verilmiştir. Bundan ötürü öğrenciler bu süreçte sadece şiir çözümleme başarısı kazanmakla kalmamış; cümle, tamlama, sözcük gibi yapılarla ilgili hem biçimsel hem de anlamsal çözümleme yapma noktasındaki bilgilerini de artırmışlardır. Bu yargıya öğrencilerin etkinliklerdeki başarılarının istikrarlı bir şekilde artmış olmasından hareketle ulaşılmıştır. Bu konu ile ilgili Dunning (1966) de, etkili bir şiir öğretimi için şiire çoğul bakış açısıyla yaklaşmanın gerekli olduğunu, şiir öğretim sürecinde birden çok yaklaşımın göz önünde bulundurulması gerektiğini ifade etmiştir. Buna ek olarak araştırmacı, şiir öğretiminin çok yönlü, yani öğrencilerin hem duyuşsal hem de bilişsel yönlerini harekete geçirici nitelikte yapıldığında daha başarılı sonuçlar elde edilebileceğini belirtmiştir.

Meram Yayınları 7. Sınıf Türkçe Dersi Öğretmen Kılavuz Kitabı, şiir öğretimi açısından incelendiğinde şiirle ilgili etkinliklerde şiirin bütün unsurlarının birlikte ele alındığını söylemek güçtür. Söz gelimi "Bayrak" şiiri ile ilgili öncelikle okuma çalışmalarına, daha sonra metni anlamaya yönelik etkinliklere yer verilmektedir. Araştırmadan elde edilen sonuca göre bu yaklaşım tarzı, öğrencilerin şiir çözümleme başarılarına anlamlı şekilde etki etmemektedir. Diğer taraftan OMAE kapsamında araştırmaya dâhil edilen her şiirde okuma çalışmaları gerçekleştirilmiş, nazım birimi, vezin gibi unsurlar tespit edilmiş, şiirin anlam birlikleri (cümle-tamlama-sözcük) bulunmuş, anlam birlikleri ile ilgili semantik temelli etkinliklere yer verilmiş, şiirde ön plana çıkan işlevsel dil yapıları ve bunların anlama ne kattığı vurgulanmış, şiirin anahtar sözcüğü bulunmuş, son olarak da genellenebilir düşünceler/duygular üzerinde durulmuştur. Özetle OMAE kapsamında şiirlerin daha geniş bir bakış açısıyla incelendiği söylenebilir. Bu durumun ise öğrencilere şiire, geniş bir açıdan bakma imkânı verdiği ve başarılı olma şansı sunduğu ifade edilebilir. Bu çerçevede Karadeniz (2012), şiir çözümlemede modern yaklaşımların kullanılmasıyla ilgili alan uzmanlarının da görüşlerine başvurduğu çalışmasında; öğrencilerin metne farklı bakış açılarıyla yaklaşabilmeleri, derinlemesine incelemelerle yorum becerilerini geliştirebilmeleri için ontolojik metin 
analizi gibi metni her yönüyle derinlemesine sorgulamaya ve değerlendirmeler yapmaya imkân tanıyan modern yaklaşımların kullanılması gerektiğini vurgulamıştır.

ŞÇF ön test puanları, öğrencilerin şiire nasıl yaklaşılacağını bilmediklerini ortaya koymaktadır. OMAE, şiiri belirli bir plan dâhilinde inceleme fırsatı vermektedir. Bunun temeli, yapıdan anlama ulaşmaktır. Çalışmanın kuramsal bölümünde ontolojik metin analizi yöntemi ayrıntılı olarak tanıtılmıştır. İlgili bölümde de ifade edildiği üzere OMAE öğrencilere şiirin nasıl tahlil edileceği ile ilgili bir çerçeve sunmaktadır. Bu sebeple OMAE temelli yapılan şiir öğretimi, daha etkili sonuçlar ortaya koymaktadır. $\mathrm{O}_{1}$ ve $\mathrm{O}_{2}$ deney grubu öğrencilerinin son test şiir çözümleme puan ortalamalarının artış göstermesinin yanında, şiir tahlili konusunda da bir bilinç ve yeterlilik kazanmış olmaları bunun kanıtı olarak gösterilebilir.

OMAE, şiiri sadece anlam bakımından çözümleme çabası değildir. Uygulama sürecinde cümle, tamlama, sözcükler üzerinden dil bilgisi çalışmalarına sıkça yer verilmiş ve öğrencilerin süreç içerisinde başarı grafiklerinin yükseldiği sonucuna ulaşılmıştır. Öğrencilerin daha önce bu konuları görmüş olmalarına rağmen ilk etkinliklerde özellikle de cümleleri tespit etmekte zorlandıkları, OMAE temelli yürütülen şiir çalışmalarıyla birlikte bu konuda gelişme kaydettikleri görülmüştür. Bu durumun temel sebebinin metinle, yani şiirle öğretim olduğu söylenebilir. Çünkü öğrencilerden şiirdeki anlam birliklerini bulmaları istendiğinde, öğrenciler ilk etkinliklerde daha önceki bilgilerine göre sonunda nokta ya da üç nokta olan her mısrayı cümle olarak kabul etmiş ve dolayısıyla yanlış yapmışlardır. Daha sonraki etkinliklerde anlamın nerede tamamlandığına yoğunlaşmalarıyla bu hususta başarılı olmuşlardır. Bu durum dil bilgisi konularını metinden kopuk şekilde anlatmanın, olumlu sonuçlar doğurmayacağını göstermektedir. Dil kurallarının bağlam içinde anlam kurmada temel görev gördükleri düşünüldüğünde metinle öğrenme daha anlaşılır hâle gelecektir. Güneş (2013), "metinle öğrenme” konusunu ele aldığı çalışmasında, metinle öğrenmenin öğrencilerin temel dil becerileri ile birlikte sosyal, duygusal ve zihinsel becerilerinin geliştirilmesinde de çok önemli bir husus olduğunu söylemiştir. Metne dayalı dil bilgisi öğretimi konusunu ele alan Erdem ve Çelik (2011) ise dil bilgisinin temel dil becerilerini geliştirebilmesi için metinden en azından cümleden hareketle, işlevsel bir şekilde öğretilebileceğini; ezberden kurtulmak için tanımdan örneklere değil örnekten sezdirme yoluyla kurala ulaşılacak bir yaklaşımın kullanılması gerektiğini ileri sürmüşlerdir. Araştırmadan elde edilen sonuçla ilişkili olarak Göçer ve Sayın (2014), Türkçe kılavuz kitaplarını inceledikleri ve bu konuda Türkçe öğretmenlerinin görüşlerine başvurdukları çalışmalarında, dil bilgisi konularının ilgili ana metin ile ilişkili olmadığı, diğer dil becerileriyle bir bütün olarak öğretim yapılmadığı, farklı bir dersmiş gibi ayrı ders saatinde işlendiği sonucuna ulaşmışlardır. Bu sonuç da metinden kopuk dil öğretiminin başarıya ulaşamayacağını göstermektedir.

Son yıllarda metinlerin farklı açılardan hareketle incelendiğinde daha anlaşılır, öğrencilerin temel dil becerilerinin geliştirilmesinde daha faydalı olabileceği ciddi anlamda tartışılmış ve teorisyenlerce yeni eleştiri yaklaşımları geliştirilmiştir. Özellikle şiir metinlerinin analizinde bu yeni yaklaşımların kullanılması, öğretim ortamlarına taşınması önemsenir hâle gelmiştir. Bu kapsamda çalışmada kullanılan ontolojik metin analizinin, öğrencilerin hem şiir çözümleme başarılarının hem de temel dil becerilerinin geliştirilmesinde etkili bir yaklaşım olduğu tespit edilmiştir. Bunda yaklaşımın farklı ve bütüncül bir bakış açısı sunmasının etkili olduğu söylenebilir. Bu sonuçla ilgili olarak Kılıç (2002), Türkçe derslerinde metni farklı bakış açılarıyla işlemenin anlama düzeyini olumlu yönde etkilediğini ifade etmiştir. Chemwei, Kiboss ve Ilieva (2005) ise iş birlikli öğrenmenin şiir öğretimine etkisini araştırmış ve iş birlikli öğrenmenin öğrencilerin şiir çözümleme başarılarını artırdığını ortaya koymuşlardır.

Bir yaklaşımın tüm metinlerin analizinde kullanılabileceğini veya bir metnin tek bir yaklaşımla analiz edilebileceğini düşünmek de aynı şekilde ele alınabilir. Yani değerlendirilecek olan metne göre doğru yaklaşımı belirleyip o doğrultuda tahlil yapmak daha tutarlı sonuçlar verebilir. Bunun için öncelikle öğretici tarafından işlenecek metin duru bir dikkatle okunmalıdır. Daha sonra o metne hangi yaklaşım uygunsa o yaklaşım temelli öğretim yapılmalıdır. Bir metnin öğretiminde birden çok yaklaşımı kullanmak da gerekebilir. Eğer metnin daha iyi anlaşılabileceği düşünülüyorsa birkaç yaklaşım birlikte kullanılarak ders planı ve etkinlikler oluşturulabilir. Böylelikle süreç öğrenciler açısından hem daha eğlenceli bir hâle gelir hem de başarı daha anlamlı şekilde gerçekleşmiş olur.

Çalışmada kullanılan etkinliklerde şiir metinleri yapı bakımından incelenirken anlam da göz ardı edilmemiştir. Ontoloji, bu iki unsurun bütünlüğü olduğu için yapı ve anlam incelemelerine birlikte yer verilmiştir. Sözcük çalışmalarında anlam alanlarına yoğunlaşılması içeriğin önemsendiğini gösteren bir durumdur. Sözcüklerin çağrışım alanları yanında mısra, bent veya dörtlüklerdeki örtülü anlamlar da sorgulanmış, öğrencilerin duygu ve düşüncelerini sözlü ya da yazılı olarak ifade etmelerine imkân tanınmıştır. Bu uygulamalardaki amaç öğrencilerin eleştirel düşünme, problem çözme, yorum ve değerlendirme gibi üst düzey becerilerini geliştirmek olmuştur. Araştırma sürecinde yapılan gözlemler, şiir metinlerinin bu becerilerin öğretiminde daha elverişli olduğunu, 
öğrencileri daha başarılı kıldığını göstermiştir. Yani öğrencilerin gerek temel dil becerilerinin gerek düşünme becerilerinin geliştirilmesinde şiir kullanılabilir bir araçtır.

Demir ve Duman (2004), şiirin yüzyıllar boyu öğretimde kullanıldığını, Hz. Muhammed'in hayatının anlatıldığı siyer kitaplarının, çeşitli konuları işleyen mesnevilerin, İslam hukukunu anlatan fıkıh eserlerinin şiir türünde olduğunu ifade etmişlerdir. Onlara göre sözcüklerin doğru telaffuzunun ve anlam bakımından öğretimi şiirle mümkün olabilir ve dil öğretimi şiire dayalı bir metodolojiye göre yapıldığında öğrencilerin dili sevmeleri ve o yönde bilinç kazanmaları sağlanmış olur. Yıldırım (2012) da şiirin, öğrencilerin gerek duygusal gerek düşünsel gerekse dilsel gelişimlerinde önemli bir yerinin olduğunu ortaya koymuştur.

Okuma yazma öğretiminde şiirin yerini araştıran Kaya'ya göre (2013) ise şiir; dili, düşünceyi, eleştirel düşünmeyi, yaratıcılığı, duyuları, duyguları, müzik ve ritmi aynı anda etkili bir şekilde bir araya getirdiği için yazma öğretiminin başarısında büyük bir pay sahibidir. Aynı şekilde Boyd de (1973) şiirdeki ritim ve kafiyenin okurlara zevk verdiğini ifade ederek şiirin öğrenciler için bir intiyaç olduğunu ve öğrencilerin okuma yazma becerilerinin geliştirilmesinde önemli bir yerinin olduğunu belirtmiştir. Stanley (2004) şiir öğretimi ile öğrencilerin okumada telaffuz, sesletim veya konuşmada diksiyon becerilerinin gelişebileceğini ifade etmiştir. Şiir öğretiminin öğrencilerin eleştirel düşünme becerilerini geliştirdiğini ifade eden Sloan (1984) ise dil çalışmalarının temeline edebî metinleri, özellikle de şiiri koymuştur.

Araştırmanın bu bölümüyle ilgili ulaşılan sonuç geniş çerçevede ifade edilecek olursa OMAE, yedinci sınıf öğrencilerinin şiir çözümleme başarılarının geliştirilmesinde etkili olmuştur. Bunun yanında öğrencilerin Türkçe dil bilgisi yeterliliklerinin, farklı şekillerde düşünebilme becerilerinin, metinlere değişik açılardan yaklaşabilme yeteneklerinin de ilerlediği gözlenmiştir.

\section{5. Öneriler}

1. Elde edilen sonuçlara göre OMAE 7. sınıf öğrencilerinin şiir çözümleme başarılarını artırmaktadır. Bu sebeple bu yöntem doğrultusunda hâlihazırda uygulanan etkinlikler gözden geçirilebilir. Var olan etkinliklere eklemeler yapılabilir.

2. OMAE, şiirle ilgili öğrencilere çoklu bir yaklaşım imkânı sunmaktadır. Hazırlanan etkinliklerin uygulanması sırasında uygulayıcı öğretmenlerce bu durum tecrübe edilmiş ve araştırmacının gözlemleri de bunu ortaya koymuştur. Dolayısıyla serbest zaman etkinliklerinde veya ders içinde firsat buldukça OMAE ile şiir değerlendirme çalışmalarına yer verilebilir. Öğrencilerin sevdikleri şiirler bu dikkatle incelenebilir. Böylelikle öğrencilere birçok beceri aynı anda kazandırılabilir.

3. OMAE ile tasarlanmış yeni ders planlarıyla farklı sınıf düzeylerinde araştırmalar yapılabilir. Bu etkinliklerin farklı sınıflarda şiir öğretimine etkisi ortaya konulabilir.

4. Ortaokul öğrencilerinin konuşma ve yazma becerilerinin geliştirilmesinde OMAE kullanılabilir. Bu etkinliklerle şiir öğretimi daha etkili bir süreç hâline dönüştürülebilir. Böylelikle öğrencilerin çoğunluğunun derse daha çok ilgi duymaları sağlanabilir.

5. Bu araştırmada OMAE’nin öğrencilerin şiir çözümleme başarılarını artırdığı görülmüştür. Şiir çözümleme amaçlı kullanılan diğer modern yaklaşımlar da bu hususta uygulanabilir. Deneysel sürece dayalı sonuçlar paylaşılabilir.

6. Bu araştırmanın ve alanda yapılacak çalışmaların sonuçlarına göre hem Türkçe Öğretim Programı'nın hem de ders materyallerinin içerikleri gözden geçirilebilir. Gerekli görülen eklemeler yapılabilir.

\section{Kaynakça}

Açık Önkaş, N. (2010). Türkçe eğitiminde fonetik-semantik ilişkili şiir öğretimi. Elektronik Sosyal Bilimler Dergisi, 9(34), 80-97.

Aksan, D. (2011). Cumhuriyet döneminden bugüne örneklerle şiir çözümlemeleri. İstanbul: Bilgi Yayınevi.

Altunkaya, H. (2013). Necip Fazıl Kısakürek'in “Ben” şiirinin ontolojik tahlil yöntemi ile çözümlenmesi. Birey ve Toplum Dergisi, 3(5), 137-154.

Aykanat, T. (2013). Ontolojik çözümlemeyle Şeyh Gâlib'in bir gazeline yapısalcı yaklaşım. International Journal of Social Science, 6(1), 351-370.

Aytaş, G. (2006). Edebî türlerden yararlanma. Millî Eğitim Dergisi, 169, 10-18.

Baş, B. (2015). Türkçe öğretimi açısından çocuk edebiyatı. Ankara: Pegem Akademi Yayıncılık.

Bayram, Y. (2003). Ontolojik analiz metodu ve bir uygulama. Yom Sanat (Mayıs-Haziran), 12-15.

Binyazar, A. ve Öztekin, M. (1978). Yazın ve bilim dilimiz. Ankara: Türk Dil Kurumu Yayınları.

Bizzaro, P. (1990). Evaluating student poetry writing: A primary trait scoring model.Teaching English in the Two-Year College, 17(1), 54-61. 
Bizzaro, P. (1993). Pesponding to student poems: Applications of critical theory. Urbana: National Council of Teachers of English.

Boyd, G. A. (1973). Teaching poetry in the elementary school. Columbus: Charles E. Merrill Publishing Company.

Büyüköztürk, Ş. (2004). Sosyal bilimler için veri analizi kitabı. Ankara: Pegem A Yayıncılık.

Büyüköztürk, Ş., Kılıç Çakmak, E., Akgün, Ö. E., Karadeniz, Ş., ve Demirel, F. (2009). Bilimsel araştırma yöntemleri. Ankara: Pegem Akademi.

Cahnmann, M. (2003). The craft, practice, and possibility of poetry in educational research. Educational Researcher, 32(3), 29-36.

Carter, D. (2012). Teaching poetry in the primary school. London ve New York: Routledge Taylor \& Francis Group.

Chemwei, B., Kiboss J. K. ve Ilieva, E. (2005). Effects of cooperative learning on teaching poetry. Thinking Classroom, 6(4), 25-33.

Collom, J. (1985). Moving windows: Evaluating the poetry children write. New York: Teachers \& Writers Collaborative.

Deger, M. B. (2015). Hayâlî́nin "bilmezler" redifli gazelinin ontolojik analiz yöntemiyle incelenmesi. Gazi Üniversitesi Sosyal Bilimler Dergisi, 2(3), 60-74.

Demir, M. ve Duman, B. (2004). Şiir okumaya dayalı Türkçe öğretimi. Ilmî Araştırmalar Dergisi, 17, 89-98.

Demircan, S. (2014). Necip Fazıl’ın "Karacaahmet" şiirine ontolojik bir yaklaşım denemesi. Sosyal Bilimler Araştırma Dergisi, 24, 155-169.

Dunning, S. (1966). Teaching literature to adolescents: Poetry. New York: Scott, Foresman and Company Press.

Erdem, ì. ve Çelik, M. (2011). Dil bilgisi öğretim yöntemi üzerine değerlendirmeler. Turkish Studies, 6(1), 1030-1041.

Esbensen, B. J. (1975). A celebration of bees: Helping children write poetry. Minneapolis: Winston Press.

Göçer, A. ve Sayın, H. (2014). 6, 7 ve 8. Sınıf Türkçe kılavuz kitaplarındaki metinlerin dil bilgisi öğretimindeki yeterliliği ve kullanım durumlarının incelenmesi. Journal of European Education, 4(2), 11-28.

Güneş, F. (2013). Türkçede metin öğretimi yerine metinle öğrenme. Adıyaman Üniversitesi Sosyal Bilimler Enstitüsü Dergisi, 11, 603-637.

Güney, N. (2016). Öğretmenlerin yazma eğitimine yönelik görüşleri. Uluslararası Türkçe Edebiyat Kültür Eğitim Dergisi, 5(2), 970985.

Gürbüz, A. (2014). Tevfik Fikret'in “Ramazan Sadakası” şiirinin ontolojik analiz metoduyla çözümlenmesi. Turkish Studies, 9(6), 469483.

Harmer, D. (2000). Poetry in the primary school. Arts in Primary Education, 28(2), 15-18.

Hazer, G. (2014). Ontolojik tahlil metoduyla ahmet muhip dıranas'ın "yaşarken” şiirinin incelenmesi. Akademik Bakış Dergisi, 41, 1-13.

Hunley, T. C. (2007). Teaching poetry writing. Toronto: Multilingual Matters.

İçli, A. (2008). Necati'nin bir şiirinin ontolojik analiz yöntemiyle incelenmesi. E-Journal of New World Sciences Academy. 4(1).

Issı, A. C. (2004). Turgut Uyar'ın “Göğe Bakma Durağı” şiirinde tema'ya (matris) ulaşma serüveninin 'ontolojik analiz metodu’yla takibi. Gazi Üniversitesi Kırşehir Eğitim Fakültesi Dergisi, 5(2), 137-146.

Karadeniz, A. (2012). Modern çözümleme yöntemlerinin şiir çözümleme becerisine etkisi ve şiir öğretiminde kullanılabilirliği. Yayımlanmamış doktora tezi. Gazi Üniversitesi Eğitim Bilimleri Enstitüsü, Ankara.

Karatay, H. (2011). Çocuk Edebiyatı Metinlerinde Bulunması Gereken Özellikler. Tacettin Şimşek (Ed.). Kuramdan Uygulamaya Çocuk Edebiyatı El Kitabı içinde (s. 77-125). Ankara: Grafiker Yayınları.

Kardaş, S. (2014). Nâbî’nin "gelür gider" redifli gazelinin ontolojik analiz yöntemiyle yorumlanması. Uluslararası Sosyal Araştırmalar Dergisi, 7(29).

Kaya, M. (2013). Okuma-yazma öğretiminde şiir. Dil ve Edebiyat Dergisi, 10(1), 49-96.

Kıbrıs, İ. (2008). Okuma ve yazma çalışmalarında şiir etkinliklerinden nasıl yararlanılabilir? Abant İzet Baysal Üniversitesi Eğitim Fakültesi Dergisi, 8(1), 53-66.

Kılıç, A. (2002). Bir metni farklı bir şekilde işlemenin anlama düzeyine etkisi. Eğitim ve Bilim Dergisi, 27 (103), 53-61.

Kilmen, S. (2015). Eğitim araştırmaları için SPSS uygulamalı istatistik. Ankara: Edge Akademi.

Köktürk, Ş. (2003). Bayburtlu Zihnî'nin bir koşmasının ontolojik analiz metoduyla incelenmesi. Millî Folklor Dergisi, 60. 
Kurudayıoğlu, M. (2003). Konuşma eğitimi ve konuşma becerisini geliştirmeye yönelik etkinlikler. Türklük Bilimi Araştırmaları Dergisi, XIII, 287-309.

Öcal, O. (2008). Kendini verememe problemi ve Ataol Behramoğlu'ndan bir örnek. Türklük Bilimi Araştırmaları Dergisi, XXIV.

Robson, C. (2015). Bilimsel araştırma yöntemleri. (Çev. Ed. Şakir Çınkır ve Nihan Demirkasımoğlu). Ankara: Anı Yayıncılık.

Sarıçiçek, M. (2008). Şehriyar’a selam Haydar Baba'ya selam'ın ontolojik tahlili. Turkish Studies, 3(7), 580-591.

Seçer, i. (2013). SPSS ve LISREL ile pratik veri analizi. Ankara: Anı Yayıncılık.

Sloan, G. D. (1984). The child as critic: Teaching literature in elementary and middle schools. New York: Teachers College Press.

Smith, R. J. (1985). Using poetry to teach reading and language arts: A handbook for elementary school teachers. New York: Teachers College Press, Columbia University.

Spiro, J. (2007). Teaching poetry: Writing poetry-teaching as a writer. English in Education, 41(3), 78-93.

Stanley, N. (2004). Creating readers with poetry. Gainesville: Maupin House Publishing.

Taşkesen, M. (2015). Yavuz Bülent Bâkiler'in "Şaşırdım Kaldım İşte" adlı şiirinin ontolojik tahlil yöntemi ile çözümlenmesi. International Journal of Languages' Education and Teaching, Udes 2015, 1779-1789.

Tökel, D. A. (2003). Anlama götüren kilometre taşları: Divan şiirini redifine göre yorumlamak. Yom Sanat, 11, 39-43.

Tökel, D. A. (2007). Divan şiirine modern metin çözümleme yöntemlerinden bakmak. Turkish Studies, 2(3), 535-555.

Tsujimato, J. I. (1988). Teaching poetry writing to adolescents. Urbana: National Council of Teachers of English.

Tunalı, ì. (2011). Estetik beğeni. İstanbul: Remzi Kitabevi.

Tunalı, I. (2014). Sanat ontolojisi. İstanbul: İnkılâp Kitabevi.

Türk Dil Kurumu. (2011). Türkçe sözlük. Ankara: Türk Dil Kurumu Yayınları.

Uçgun, D. (2013). Türkçe eğitiminde motivasyonu artırmaya yönelik uygulamalar. Eğitimde Kuram ve Uygulama Dergisi, 9(4), 354362.

Wellek, R. ve Warren A. (1983). Edebiyat biliminin temelleri. (Çev. A. E. Uysal). Ankara: Kültür ve Turizm Bakanlığı Yayınları.

Yardımcı, M. ve Tuncer, H. (2002). Eğitim fakülteleri için çocuk edebiyatı. Ankara: Ürün Yayınları.

Yılar, Ö. ve Celepoğlu, A. (2013). Çocuk Yayınları ve Bu Yayınlarda Bulunması Gereken Temel Unsurlar. Ömer Yılar ve Lokman Turan (Ed.). Eğitm Fakülteleri için Çocuk Edebiyatı içinde (s. 37-66). Ankara: Pegem Akademi Yayıncılık.

Yıldırım, E. (2012). Şiirin Türkçe eğitimindeki işlevi ve ilköğretim ikinci kademe Türkçe ders kitaplarındaki şiirlerin yerinin incelenmesi. Yayımlanmamış yüksek lisans tezi, Pamukkale Üniversitesi Sosyal Bilimler Enstitüsü, Denizli. 